\title{
No change in sight
}

\section{Togo's Political and Socio-Economic Development (2017 - 2019)}

\author{
Dirk Kohnert ${ }^{1}$
}

\begin{abstract}
Backed by peaceful but undemocratic presidential $(2010,2015)$ and legislative (2013) elections the Gnassingbé regime consolidated its power. In view of the absolute majority of the ruling party, its inclination for meaningful constitutional and electoral reforms, as demanded by the opposition and international donors, was further reduced. Overriding concerns for stability in West Africa in view of growing Islamist threats in neighbouring countries made that the delayed democratic reforms, including the time and again reported local elections, were condoned by the donor community. However, simmering discontent of the hardliners among the security forces and the barons of the ruling party was still visible. The opposition tried in vain to overcome its divide between its moderate and radical wing. An alliance of opposition parties and civic groups opposed the regime peacefully by frequent, often violently suppressed demonstrations with little effect. Arson attacks on the markets of Lomè and Kara in January 2013 served as pretense to harass opposition leaders. Human rights records of the government remained tarnished. The tense political climate persisted in view of the upcoming presidential elections in April 2015 and the apparent determination of the President to stay in power a third and eventually even a fourth term whatever the cost. Despite undeniable improvements of the framework and outside appearance of major institutions of the regime during the survey period it remained a façade democracy. However, the international community, notably African peers, the AU and ECOWAS, but also the Bretton-Woods Institutions, China and the EU, followed a 'laissez faire' approach in the interest of stability and their proper national interest in dealings with the country. Economic growth perspectives remained promising, expected to increase to $6.0 \%$ in 2014 and $6.3 \%$ in 2015, last but not least because of heavy assistance by the international donor community. However, growth is neither sustainable nor inclusive. It is overshadowed by increasing inter-personal and regional inequality as well as an upturn in extreme poverty.
\end{abstract}

Keywords: democratization, governance, fragile states, political and socio-economic development, development co-operation, EU, Togo, West Africa, ECOWAS

JEL-code: A14, F35, N97, O17, O55, Z13

\footnotetext{
${ }^{1}$ Author's extended and annotated version of 'BTI 2020 - Togo Country Report', amended with hyperlinks to several additional sources, references as well as a list of further readings - The 'BTI 2020 - Togo-Country Report' is part of the Bertelsmann Foundation's Transformation Index (BTI) 2020. It covers the period from 31 January 2017 to 31 January 2019. The BTI assesses the transformation toward democracy and a market economy as well as the quality of political management in 129 countries. Gütersloh: Bertelsmann Foundation, forthcoming (2020). More on the BTI at http://www.bti-project.org.
} 


\section{Executive Summary}

The Gnassingbé clan has ruled the country since 1967. The demand for political alternance, initiated by institutional and electoral reforms, constituted the major contentious issue between the government and the challengers of the Gnassingbé regime throughout the survey period. An alliance of opposition parties and civil society groups organized peaceful demonstrations in opposition to the regime, which were often violently suppressed. Civil society organizations and representatives of the Christian church supported the demands of the opposition. The protest of the notoriously divided opposition took a new momentum since August 2017 with the lead by a hitherto hardly known opposition party and its charismatic leader, Tikpi Atchadam. The legislative elections of 20 December 2018, boycotted by the major opposition parties, resulted in the an easy victory of the ruling party, however without the expected constitutional amendment majority. The local elections, crucial for democratization at the grass-roots, but postponed time and again since 1987, were again postponed in December 2018 sine die. The simmering discontent of hardliners within the security forces and the ruling party remained a potential threat. The opposition tried unsuccessfully to overcome internal divisions between its moderate and radical wings. The human rights record of the government has improved but remains poor. Despite undeniable improvements to the framework and appearance of the regime's key institutions during the review period, democracy remains far from complete. However, the international community, notably Togo's African peers, the $\underline{\mathrm{AU}}$ and ECOWAS, followed a 'laissez-faire' approach in the interests of regional stability and their national interests in dealing with Togo. Economic growth remained stable at about 5\% per annum. Public investment in infrastructure (e. g. roads, harbour) and increases in agricultural productivity, notably of export crops, had been the key drivers of economic growth. However, growth remains vulnerable to external shocks and the climate and has not been inclusive. Positive growth was overshadowed by increasing inter-personal and regional inequality as well as an increase in extreme poverty. Moreover, money-laundering, illegal money transfers and trafficking grew alarmingly. The business climate improved considerably nevertheless. Though the World Bank still defines Togo as low-income, fragile state, the government aims to achieve the status of a developing economy.

\section{History and Characteristics}

Togo, established in 1884 as a German colony Togoland, became a U.N. trusted territory under French administration following World War II and wrested its independence from France on 27 April 1960. In the first democratic presidential elections of 1961, Sylvanus Olympio became president of the newly independent Togo. His assassination, on 13 January 1963, by a group of Togolese veterans of the French colonial army, led by Sergeant Etienne Gnassingbé (later called Eyadéma) was the first violent coup in the history of independent Sub-Saharan Africa. After another coup d'état on 13 January 1967, ousting President Nicolas Grunitzki, Ltd. Col. (later General) Gnassingbé Eyadéma became president of Togo on 14 April 1967. Establishing a one-party government, Eyadéma ruled as Togo's authoritarian head of state for 38 years. In July 1991, influenced by the implosion of the Soviet empire and by apparently successful democratization efforts in a number of African countries - including neighbouring Benin - a Sovereign National Conference was organized with the objective of deciding on the country's new constitutional and political order. The assembly opted for a semi-presidential system and elected an interim prime minister. Four months later, however, President Eyadéma ordered the army to attack the interim government, re-establishing his 
dictatorial power. The political persecution of opponents over the following two years triggered an unprecedented wave of migration in which some 350,000 refugees fled to Togo's neighbouring countries Benin and Ghana as well as to Europe. In 1993, the European Union, and other major international and bilateral donors (e.g., Germany), officially suspended development cooperation with Togo due to gross human right abuses. Notwithstanding political support from Paris, the substantial reduction in international aid and the decline in inward investments had severe effects on the country's economy.

When Gnassingbé Eyadéma died unexpectedly in February 2005 after nearly four decades of autocratic rule, the military proclaimed Faure Gnassingbé, one of the sons of the late president, the new head of state. Widespread international protests compelled the new president to call presidential elections on 24 April 2005. Despite international protests against massive electoral irregularities, Faure Gnassingbé was sworn in as president on 4 May 2005. The majority of the Togolese population protested against this manipulation of the public will, but the military brutally brought down the protests. About 700 people died, and more than 40,000 citizens migrated into neighbouring countries. The economy of the country further declined. Finally, massive international pressure forced the government into negotiations with the opposition political parties and civil society groups. This resulted in the so-called Global Political Accord (GPA, APG in French) in August 2006. The first free parliamentary elections took place on 4 October 2007. The then governing party, the Rassemblement du Peuple Togolais (RPT, since 2012 renamed Union for the Republic, UNIR), won an overwhelming majority under questionable frame-conditions. Contested presidential elections in March 2010 and April 2015 paved the way for a second and third five-year mandate for Faure Gnassingbé.

\section{Status Index}

\section{Democracy Status}

\section{Q1 | Stateness}

\section{Q1.1 | Monopoly on the use of force}

Togo still belongs to the impoverished fragile states according to OECD criteria. The state's monopoly on the use of force is guaranteed in principle over all its territory and population. However, a long-standing culture of impunity for extra-legal killings committed by the security forces persists. The army, gendarmerie and police are loyal to the incumbent government, apart from rivalries within its own ranks. The security apparatus is substantial for such a small country. It consists of the Togolese Armed Forces (Forces armées togolaises, FAT), including the army, navy, air force, and gendarmerie with an estimated total of 11,000 military as well as the secret service (Agence Nationale des Renseignements, ANR, number of personnel unknown) and the police. The para-military gendarmerie (Gendarmerie Nationale Togolaise), a branch of the armed forces(2,710 gendarmes), includes a special unit of intervention (l'Unité Spéciale d'Intervention de la Gendarmerie, USIG), created to fight terrorism and banditism). The elite presidential bodyguard (a branch of the Armed Forces) is, reportedly trained by Benjamin Yeaten, an internationally wanted Liberian military commander and war criminal (wikipedia). The national police (Police nationale togolaise) comprises about 4,000 members according to Interpol. In times of elections, an additional 
Election Security Force (Force sécurité élections, FOSE) composed of personnel of the gendarmerie and the national police (total 8.000) is charged to secure the elections.

The loyalty of all these security units goes back to historically grown strong ethnic (Kabyé) and interpersonal links between the army leadership and the presidential extended family. The power struggle within the Gnassingbé clan, and between hardliners and modernizers among its followers in the security forces and the ruling party (RPT/UNIR), was decided in favour of the president. In September 2011, the assumed ringleaders of a 2009 coup attempt were convicted by a Lomé court which re-enforced the command by the president. Faure`s younger half-brother and former defence minister Kpatcha as well as other family members, the retired army chief, General Assani Tidjani, and Abi Atti, a commander of the gendarmerie, were served partly long prison sentences. Their continued unlawful imprisonment was repeatedly criticized by the ECOWAS court of justice (2013 and 2014) as well as by the United Nations (February 2015). In May 2018 Kpatcha was hospitalized urgently because of serious illness, however, he was not released.

According to U.N. reports, Togo has become a major hub of drug trafficking and moneylaundering in West Africa related among other things to profits from re-exports of used cars from western Europe to neighbouring markets (mostly smuggling to Nigeria). According to the U.N. Office on Drugs and Crime (UNODC), the proceeds of trafficking are increasingly used by Islamist terrorist groups. Another domain of illicit trade was smuggling of African ivory to Vietnam and China. According to a scientific investigation published on 19 September 2018, the trade is dominated by three criminal cartels, one of them based in Lomé which coordinates the shipment of ivory for the whole of West Africa. The other two cartels were located in East Africa, in Mombasa and Entebbe. A first big catch was reported already in January 2014 when 4 tons of ivory were exported clandestinely via Lomé to Vietnam and China. Ivory poaching thus contributed to a decrease of forest elephants in that region by more than $60 \%$ in the past decade, killing $10 \%$ of the continent's 400,000 surviving elephants every year.

Moreover, piracy of the coast of West Africa - particularly in the Gulf of Guinea around Nigeria, Benin and Togo- had become a new international 'hot spot'. The region was classified as high-risk zones by maritime insurance companies. Since June 2013 the Joint War Committee (JWC) added the waters of Togo's exclusive economic zones north of latitude $3^{\circ}$ to the West Africa high-risk area. Many of these pirates are said to be Nigerian gangs, cooperating with politicians, the military and customs officials, with intimate knowledge of the oil industry and oil tankers, probably derived from previous experience in the Nigerian Niger Delta. According to the Piracy Reporting Centre of the International Chamber of Commerce's International Maritime Bureau (IMB), the Gulf of Guinea accounted for 29 incidents in the first quarter of 2018, more than $40 \%$ of the global total. Of 114 seafarers captured worldwide, all but one were kidnapped in this region. Especially, the hijacking of product tankers from anchorages in the Gulf of Guinea was a cause of concern. In most cases, the intent of the perpetrators was to steal the oil cargo and to kidnap crew. On new year's eve 2018/19 a Russian cargo carrier, the MSC Mandy was attacked by pirates on the way from Lomé to Cotonou, shortly after having left Togolese territorial waters. Six of her crew of 26, among them the captain and the first and third officer, were kidnapped, apparently in search of ransom, and the cargo plundered. 
Map of piracy attacks West-Africa, 2017

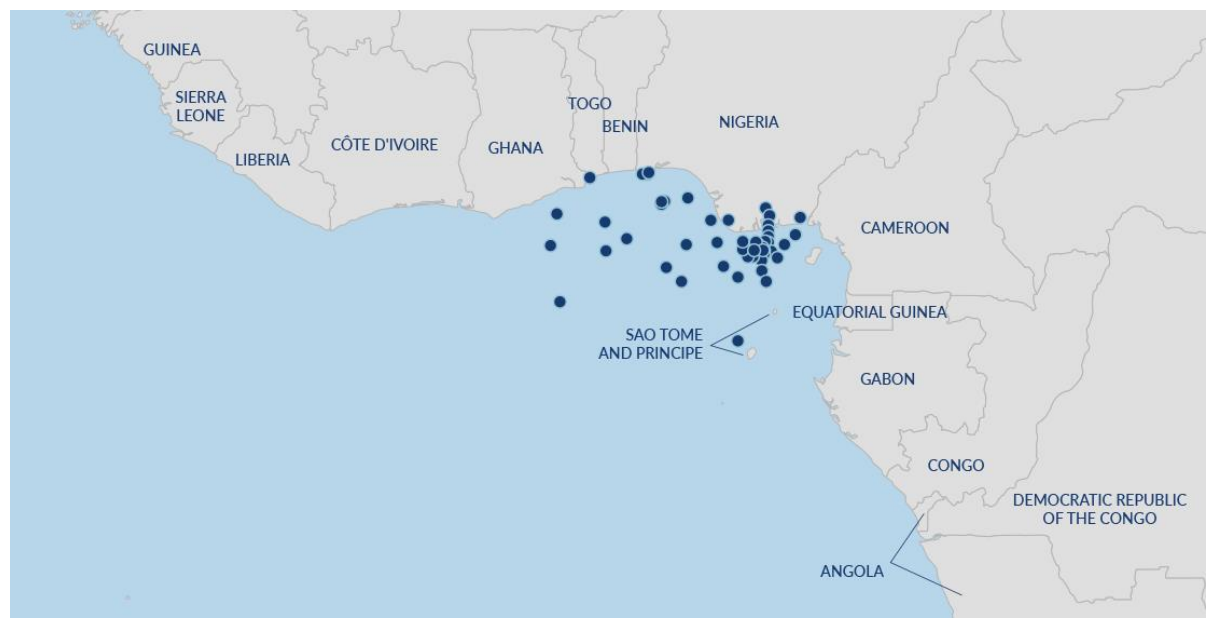

Source: OBP-OceansBeyondPiracy.org, 2018

In October 2018 Togo and Benin jointly deposited at the UN a demand for the extension of their respective continental shelf from 200 to 350 nautical miles, after their preliminary information in 2009 proved with scientific data supporting the demand. The background to the extension was recent disposal of more detailed information on the riches of the sea beyond fishery resources, notably mineral resources (oil, gas etc.).

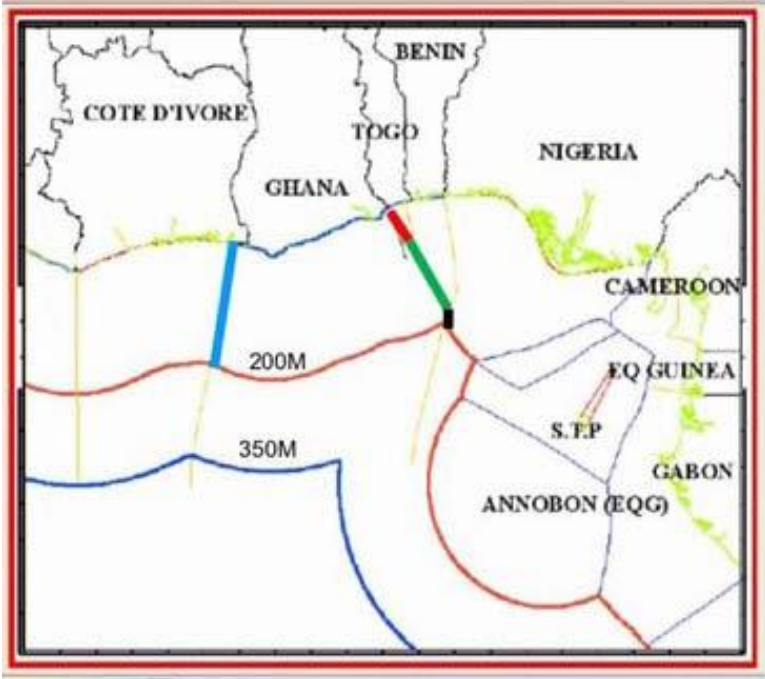

Map: maritime boundaries.

West Africa, 2017

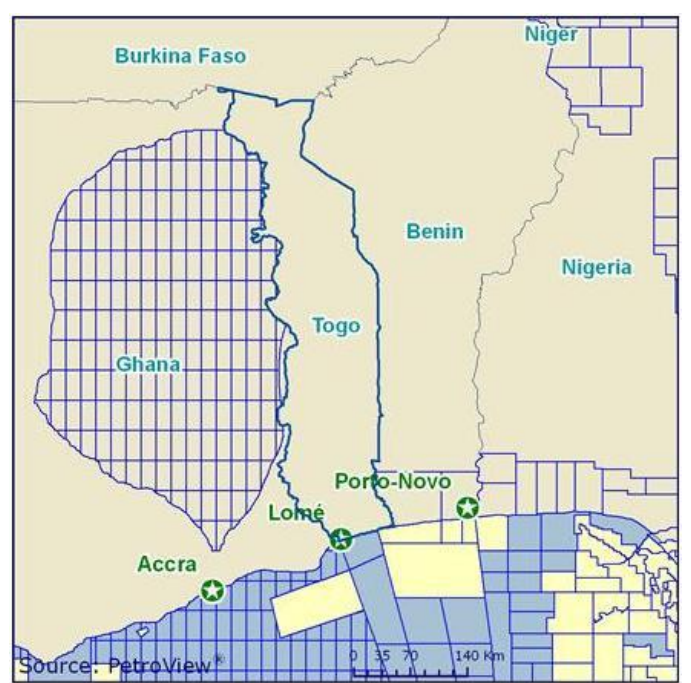

Map: Togo and Benin, oil and gas-blocks, 2011

\section{Q1.2 | State identity}

A basic patriotism is observable among the vast majority of Togolese citizens for generations. Particular dates and events in the country's history (e.g., independence day, football Championat) are inscribed into the collective memory. However, the sentiment of national belonging is often mitigated by intra-ethnic and regional cleavages. Tensions between ethnic groups, dating back to Togo's colonial past, still play a considerable role in limiting equal access to remunerative and strategically important public authorities, thereby abetting nepotism and compromising good governance. This holds particularly with respect to the divide between the Kabyé of northern Togo, who dominate Togo's politics and security 
services, and the economically more powerful Ewé of southern Togo. The lack of a consensus regarding national benchmarks to date may be an indicator of the deficient consolidation of Togo as a functioning nation-state. An example of self-interested nationalism includes calls by trading elites, like the influential 'Nana-Benz', politically influential cloth-trading women of Lomé, who during the 1970s earned more revenue than the phosphate industry, to limit market access for 'Foreigners'. These trading elites have been increasingly critical of growth in the 'unfair' competition they face from small-scale Chinese traders and Nigerians, who are often accused of drug dealing.

\section{Q1.3 | No interference of religious dogmas}

The formally established religious groups - Christians (about $48 \%$ of population, $28 \%$ Roman Catholics, $10 \%$ Protestants, $10 \%$ others), 33\% traditional African religion, 14\% Sunni Muslim (most recent data: Univ. Lomé, 2004 survey; most Muslims are of the Sufi order of the Tidjaniya) - seek to play a neutral and constructive role in the political system and to make democracy more vibrant, as was observed during the National Conference of 1991, the 2007, 2013 and 2018 legislative elections as well as the active participation in the Truth and Reconciliation Commission (Commission Vérité, Justice et Réconciliation) since 2009. Numerous animated Pentecostal and evangelical free churches (about 12,000, often just one man shows), had applied for official registration up to September 2015, but are less active in secular public life. Approximately 900 remained pending end of 2017. The Ministry of Territorial Affairs (MTA) continued to organize meetings with religious leaders and communities to discuss pending draft legislation regarding religious freedom (US-Gov, 2018). The government did not approve any pending registration, nor did it accept new applications, because many of these groups exacerbate tensions by encouraging intolerance, commercial orientation and extremely conservative attitudes, including the incorporation of sinister elements of traditional belief systems, such as witch hunting. The same holds for the few Quran schools in the country led by radical imams. The religious cohabitation was disturbed the first time in July and August 2018 when four mosques in the suburbs of Lomé were looted by unknown perpetrators. The conference of bishops of the Catholic church as well as the Union of Muslims, civil society organisations and the government unanimously condemned these desecrations.

African traditional religions, notably Vodun in the southern regions and occult belief systems all over Togo, still play an important role in everyday life. Their priests often act as esteemed conflict mediators at the local level. However, the past instrumentalization of African religions and occult belief systems by the ruling powers for political means and politically motivated witch-hunts, as demonstrated by the now-defunct Eyadéma regime, can be revived at any time.

\section{Q1.4 | Basic administration}

Whereas the state's basic administration extends throughout the entire territory, it is functionally deficient. Key public goods are not available to large parts of the population. Only $13.9 \%$ of the population has access to improved sanitation facilities and $62.8 \%$ to improved drinking-water sources (HDR, 2018).

The basic public administration continues to suffer from the parallel structures of formal and informal institutions (e.g., traditional chieftaincies) inherited from colonial rule. In addition, the legitimacy crisis left behind by decades of despotic rule and growing corruption in a 
fragile economic environment are barriers to good government and a transparent administration. The state's administrative organizational structure is centralized. The political elite still lacks the political will to devolve power and resources in order to enhance local autonomy, as demanded by the constitution, the opposition and the donor community. Local elections have been repeatedly postponed since 1987 when the last communal elections were held. On 12 June the Constitutional Court obliged the National Electoral Commission (CENI) to organize local elections before the end of 2018. Thereupon, the government fixed the date for the local election to 16 December 2018, together with a referendum on the revision of the constitution as proposed by the government. However, in December both the local election and the referendum were cancelled on short notice without official reason.

On 27 January 2018, the law on decentralisation and local freedoms of 2007 was modified with reference to the law on the creation of communes of 2017, in order to regulate the process of decentralisation. The law codified among others the number of councillors per commune, prefecture and region and the limitation of mandates of local councillors to maximal two. The commitment of the government within the Global Political Accord (APG) of 2006 to replace discredited prefects have been implemented only halfheartedly by the reshuffle of 2007 and 2009 and the replacement of prefects in February 2016 and 2018. On 27 May 2016, four new prefectures were created: Mô, Agoé-Nyivé, Oti-Sud and Kpendjal-Ouest, the latter replacing Naki-Est. On 26 January 2018, two new prefects were nominated in AgoèNyivé and Golfe prefectures, another in Oti-Sud on 3 August, and at the end of the year (28 December) the parliament complimented the law on the communes of 2017 to increase the number of communes in the prefecture of Doufelgou from two to three.
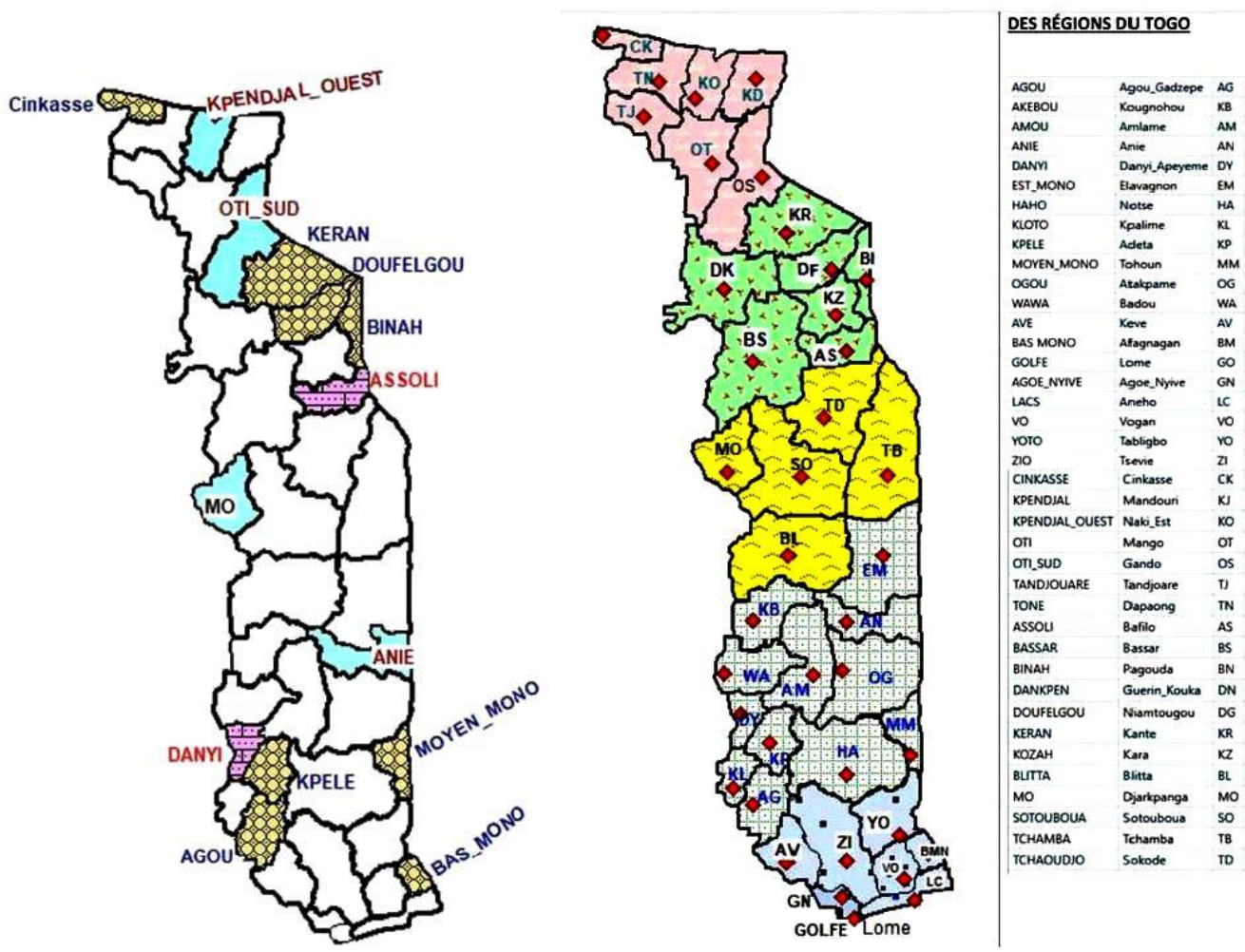

Map of new prefectures, 2017

source: Apedo, (2018): Le fichier électoral du Togo. Lomé : 29 January 2018 


\section{Q2 | Political Participation}

Q2.1 | Free and fair elections

The presidential elections of 25 April 2015 resulted in a victory for the incumbent, Faure Gnassingbé. Thus, he secured his third five-year term, consolidating the Gnassingbé clan's grip on power, which has held power since 1967. Only North Korea's ruling dynasty has held executive power for longer. The constitutional and electoral reforms that would have been required for free and fair elections according to the Global Political Agreement (2006) between government and opposition had been postponed time and again. Nevertheless, the international community declared the elections free and fair, given their security interests in the region. On the contrary, the Electoral Integrity Project (Los Angeles) ranked the presidentials 2015 as well as the legislative elections (2013) in Togo at the bottom range (rank 161 and 162 of 168) in its expert survey 2015 of 180 elections in 139 countries. The democracy index of the Economic Intelligence Unit (London, 2018) rated Togo as well as an "authoritarian regime".

According to opinion surveys in $2017,85 \%$ of the population is in favour of procedural reforms, calling for the reestablishment of a limit on presidential terms, which the late head of state Gnassingbé Eyadéma had abolished in 2002 by an illegitimate amendment of the 1992 constitution. Therefore, in September 2017, the government introduced in parliament a draft reform law of the constitution providing for a limitation of the president's mandates to two consecutive terms (however, not to be applied retroactively as requested by the opposition), and a change in the voting method used for the presidentials, with a two-round majority vote instead of a single majority vote. However, the law failed to gain the four-fifths majority necessary for a revision of the constitution. Of the 91 members of parliament, only the 61 members of the ruling party voted for it. The opposition boycotted the vote because the reform would have allowed the president to stand for a fourth and fifths term in 2020 and 2025. Nevertheless, the voting result qualified for being decided by a referendum, which was to be held on 16 December 2018, together with the local elections, i.e. shortly before the legislative elections of 20 December.

Apart from re-establishing the retroactive two-term limit for the presidency, the opposition called for revising Togo's first-past-the-post system (introduced by the 2009 electoral law, which provides the incumbent with a comfortable advantage vis-à-vis his competitors), conducting local elections and the readjustment of electoral districts. The oppositional ANC recalled its disillusioning experience of the 2007 legislative elections when the opposition was defeated although it had gained by far the most votes, i.e. $1,2 \mathrm{~m}$, against $0,9 \mathrm{~m}$ for the ruling party. However, due to the layout of the electoral constituencies (communes) in favour of the ruling party already at that time, and the seats in parliament being distributed per commune, the ruling party had gained nevertheless a large majority in parliament.

On 23 June 2017, the parliamentary majority of the ruling party UNIR voted a draft law on the creation of 116 municipalities. They were divided between the five regions and 39 prefectures of the country, including 14 new communes, whereby each prefecture enclosed at least two communes. The independent local election commissions (CELI) and their territorial jurisdictions had been reduced by decree from 42 to 38. The opposition denounced the method of delimitation as a tribalistic exercise which allegedly had the major aim to assure the maximum of communes in favour of the Gnassingbe regime. For example, the latter had created relatively more municipalities in the sparsely populated North, considered to be the traditional fief of the ruling party, compared with the densely populated South, held to be the stronghold of the opposition. On 4 December 2018, the Evangelical, Presbyterian and Methodist Churches of Togo called for a postponement of a few months of the upcoming legislative elections, denouncing the "non-consensual conditions" in which the poll would be 
held. On 7 December, Togo's Muslim organisation (l'Association des Cadres Musulmans du Togo, l'ACTM, presided by Kolani Yaya) followed suit.

Meanwhile, the opposition had continued to organise huge demonstrations for a change of political power, often reprimanded violently (see Q2.3). During the biggest demonstration shortly before the elections, on 1 December 2018, the opposition gathered more than 500,000 people in the capital and again the following Saturday, totalling about two million demonstrators across the country (Élections législatives togolaises de 2018, wikipedia).

Shortly before the official start of the electoral campaign (4 December 2018) for the legislative election, the $\mathrm{C} 14$ called for a boycott of the elections in view of the biased electoral process. However, the government continued with the preparations, among others by organizing training workshops of the high command of the regions and prefectures of the Election Security Force (Force sécurité élections, FOSE-2018). The latter consisted of 8.000 special forces, charged to secure the elections, according to the roadmap proposed by the ECOWAS in July 2018. For the legislative elections of 20. December 856 candidates of 12 political parties and 18 lists of independent candidates were registered by the CENI from 9 to 19 November. The parliamentary election was held as scheduled and resulted in an easy victory of the ruling party UNIR in view of the election boycott of major opposition parties (C14).

Parliamentary elections were held on 20 December 2018. Initially scheduled for July, they had been postponed until the ECOWAS mediation group agreed to the government's plan for the polling on 20 December. In view of the boycott of the elections by the major oppositional group of the $\mathrm{C} 14$, following the refusal of the President to cancel his proposed constitutional reforms allowing him to run for a third and eventually fourth consecutive term in 2020, the ruling party gained an easy victory, although it failed to gain the necessary majority to change the constitution (four-fifths of the 91 seats) as hoped for. According to the official results, confirmed by the Constitutional Court on 31 December 2018, the ruling party UNIR gained 59 of the 91 seats in parliament, i.e. slightly less than during the past legislatives in 2013 (61 of 91) although the major opposition parties had called for a boycott of the polls. The coalition party UFC (Union des Forces de Changement) that had not joint the boycott of the C14, won 7 seats, the oppositional New Togolese Commitment (NET) (Nouvel Engagement Togolaise) 3. The rest was divided between minor opposition parties MPDD (Mouvement Patriotique pour la Démocratie et le Développement) (2 seats) and the PDP (Partie Démocratique Panafricaine) (1 seat) as well as a relatively high number (18) of independent candidates. According to the national election commission CENI, voter turnout was $59.25 \%$, i.e. $1,869,717$ of $3,155,837$ registered voters participated, with 118,607 blank or invalid votes. 
Résultats des législatives togolaises de 2018

\begin{tabular}{|c|c|c|c|c|c|}
\hline \multicolumn{2}{|l|}{ Parti } & \multirow[t]{2}{*}{ Votes } & \multirow[t]{2}{*}{$\%$} & \multirow{2}{*}{$\begin{array}{r}\text { Sièges } \\
59\end{array}$} & \multirow{2}{*}{$\begin{array}{l}+1- \\
\nabla 3\end{array}$} \\
\hline Union pour la république & UNIR & & & & \\
\hline Union des forces de changement & UFC & & & 7 & $\Delta 4$ \\
\hline Nouvel engagement togolais & NET & & & 3 & $\Delta 3$ \\
\hline Mouvement patriotique pour la démocratie et le développement & MPDD & & & 2 & Nv \\
\hline Parti des démocrates panafricains & PDP & & & 1 & $\triangleright$ \\
\hline Mouvement des républicains centristes & MRC & & & 1 & $\Delta 1$ \\
\hline Convergence patriotique panafricaine & CPP & & & 0 & $\triangleright$ \\
\hline Union des nationalistes pour le travail & UNT & & & 0 & Nv \\
\hline Afrique togo écologie & ATE & & & 0 & Nv \\
\hline Parti pour la démocratie et le renouveau & PDR & & & 0 & Nv \\
\hline Cercle des leaders émergent & CLE & & & 0 & Nv \\
\hline \multicolumn{2}{|l|}{ Listes indépendantes } & & & 18 & $\Delta 17$ \\
\hline \multicolumn{2}{|l|}{ Votes valides } & 1751110 & 93,66 & & \\
\hline \multicolumn{2}{|l|}{ Votes blancs et nuls } & 118607 & 6,34 & & \\
\hline \multicolumn{2}{|l|}{ Total } & 1869717 & 100 & 91 & $\triangleright$ \\
\hline \multicolumn{2}{|l|}{ Abstention } & 1286120 & 40,75 & & \\
\hline \multicolumn{2}{|l|}{ Inscrits / participation } & 3155837 & 59,25 & & \\
\hline
\end{tabular}

Source: Togo's legislative elections of 2018 (wikipedia)

The 91 MPs were elected by closed-list proportional representation from 30 multi-member constituencies ranging in size from two to ten seats. Seats were allocated according to the highest average method. Whereas major donors like the EU and France did not participate in international election observation in view of the contested frame-conditions, the AU and ECOWAS participated. They congratulated the government for the peaceful conduct of the elections which they recognized as free and transparent. Besides, the ECOWAS took notice of the declaration of the government to organize local elections, which had been scheduled for 16 December but postponed sine die again, in 2019. At the same time, ECOWAS put an end to its facilitating mission during its 54. session of the heads of state in Abuja on 22 December 2018.

According to the CENI, 3,418 election observers, including 3,215 national and 203 international observers (AU, ECOWAS, Conseil de l'Entente, Community of Sahel-Saharan States (CEN-SAD) etc.) followed the elections, when in total 850 candidates had lined up in 8,498 polling stations country-wide.

\section{Q2.2 | Effective power to govern}

The president has the support of the country's administration as well as that of the security forces. He faces few major structural constraints in putting his decisions into practice. However, the president is possibly not always in command of the hardliners within the ruling party, army or secret service. Prime Minister Selom Komi Klassou, had been appointed by the president on 5 June 2015. He is an Ewé originating from Notsè and regarded as a hardliner and long-time ally of the Gnassingbé regime. He had been a member of the Politburo of the 
former unity party, the Rassemblement du Peuple Togolais (the antecedent of the ruling UNIR), and had served as a cabinet minister under both the late dictator Eyadéma and his son Faure. However, Klassou together with his government, demanded his demission on 4 January 2019, apparently in reaction to the disappointing outcome of the legislative election of 20 December 2018, when the ruling party UNIR had failed to gain the constitutional amendment majority as expected in view of the boycott of the elections by the C14. On the contrary, it had won slightly fewer seats in parliament than during the legislatives in 2013 (61 of 91) although the major opposition parties had called for a boycott of the polls. Yet, on 24 January 2019, Klassou was re-elected prime minister by the president. He will lead the cabinet of 22 ministers instead of 25 ministers in the old cabinet, all from the ruling party. 13 ministers have been reappointed, including the strategically most important minister, Yark Damehane as security minister, Robert Dussey at the foreign office, and Gilbert Bawara (public service). The resort of the defence minister remained in the hand of the president in order to prevent any coup attempts. In general, the prime minister needs the president's support more so than that of parliament if he wants to implement important public policies. However, the president does not yet enjoy full democratic legitimacy, and it remains to be seen whether the powerful military will remain loyal to the president in spite of countervailing pressure by hardliners within the army and the ruling party.

An unprecedented wave of desertions in early 2018 alarmed the command of Togo's armed forces (FAT) and the government. About 40 officers and ordinary ranks of different security forces left their position. Six of them belonged to the National Gendarmerie, commanded by Col. Yotrofei Massina, a notorious securocrat of the Gnassingbé regime, accused of torture in 2012 by the National Human Rights Commission (CNDH). These defections added to six desertions and demands to leave of four officers that had however been denied by the military hierarchy already in 2017. Three other militaries committed suicide in April and June 2018, a phenomenon that was hardly unknown until then.

\section{Q2.3 | Association / assembly rights}

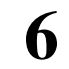

The guarantee and protection of rights to freedom of assembly and association have improved since 2007. However, limitations persist, particularly on assembly rights. The regime still interferes with demonstrations, including temporary blocks on mobile phone and internet service, to prevent social networking and it banned weekday protests. On 5 May 2011, a new bill on the right to freedom of association and assembly was adopted in parliament by the RPT/UFC majority. The new bill liberalized demonstrations by permitting demonstrations to be held without official permission, although they still can be banned if they disturb public order. However, the bill was contested by the opposition because it proposed draconian penalties for damages to public property. Member states of the UN Human Rights Council (OHCHR, Geneva), as well as Amnesty International (AI), were alarmed about continuing impunity, excessive violence of police and gendarmerie, arbitrary arrests, and restriction of freedom of expression. During an anti-government demonstration on 8 December 2018, at least two demonstrators, including a child, were shot in Lomé in the quarter of Agoè, by a special unit of intervention (l'Unité Spéciale d'Intervention de la Gendarmerie, USIG) of the Togolese Gendarmerie created to fights against terrorism and banditism. Two days later, another demonstrator was shot in Sokodé, one of the strongholds of the opposition in Central Togo, and a fourth beaten to death and burned by security forces. The government had before banned all demonstrations of the opposition that had called for a boycott of the electoral process because of gross irregularities. Already one year before, on 28 February 2017, the security forces had dispersed demonstrations in Lomé against the rise in petrol prices with 
live ammunition, killing one person and wounding several others. According to observers, the protesters had been peaceful until the police charged them with batons, tear gas and live ammunition. On 18 October 2017, four people were shot dead (one in Lomé and three in Sokodé), several injured and about sixty arrested in the course of violently suppressed antigovernment demonstrations in Lomé and Sokodé. The demonstrations took to the street although the government had forbidden demonstrations on weekdays shortly before, because of past experience with severe impairment of traffic because of demonstrator's violence, a decision which the opposition regarded as an illegal restriction of its basic rights. The demonstrations in Sokodé had been triggered by the imprisonment of an Imam close to opposition leader Tikpi Atchadam. The Imam had openly brand marked the violence of military personnel against opponents of the regime. Already before, on 20. and 21. September 2017, four demonstrators, among them one child had been shot and 25 injured during nonauthorized demonstrations in Mango in the extreme North of the country. About 500 inhabitants escaped across the border to Benin and Northern Ghana, where most of them were resettled in the refugee-camp of Chripony (LTDH, 2018). The families of the victims brought charges at the International Criminal Court (ICC), the Hague, against the responsible commander, Brigadier, Damehane Yark, one of the old stalwarts of the Gnassingbé regime, who, in his function as a minister of security, commands the police and the gendarmerie. He was notorious because of his involvement in the brutal repression of opponents during the 2005 presidential elections and figured on the index of a UN report on human rights violations in Togo. Another pillar of the regime, Félix Abalo Kadanga, brother in law of the president, who, according to a confidential UN-report, had been implied in several atrocities committed during the electoral process of 2005, became chief of staff of the FAT. He had directed the repression of the demonstrations of the opposition in 2017 country-wide and was promoted to the rank of general in April 2018. This adds to the dubious reputation of the command of the security services in general, regarding for example that presidential bodyguard was reportedly trained by Benjamin Yeaten, an internationally wanted Liberian military commander and war criminal, according to wikipedia.

AI accused the regime of having installed in August 2017 bands of militias armed with cutlasses and even firearms who attacked demonstrators in suburbs of Lomé and hotspots in the interior (Mango, Bafilo, Sokodé, Kparataou) with hooded faces. Altogether, 11 people were killed and hundreds of demonstrators were injured by militias and the security forces according to AI. Six months later, a first lot of about 30 out of 90 imprisoned opposition demonstrators were freed on 20 February as a confidence-building measure to facilitate the political dialogue having started in the capital on 19 February 2018. According to an integrated LTDH-report published on 30 July 2018, the violence in connection with the demonstrations between 19 August 2017 and 20 July 2018 resulted in 22 death, 941 injured, including 202 by bullets, and 472 arrests countrywide. 53 of the arrested persons were still in detention in July. On 8 December demonstrations in Lomé, resulted in at least two additional people killed, including one child. On 17 January 2019, one activists, Folly Satchivi, who had been arrested already on 22 August 2018 because of 'aggravated disturbance of public order', was convicted to two years of prison.

\section{Q2.4 | Freedom of expression}

Freedom of expression and the media is constitutionally guaranteed, but restricted in reality. In 2017 and 2018, anti-government demonstrations in urban centres of Lomé, Atakpamé, 


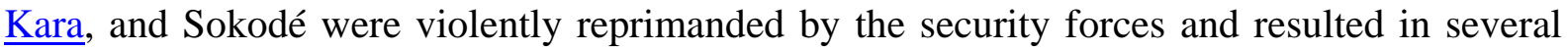
death (see Q2.3).

According to Afrobarometer (2018), just 13\% of interviewed persons (2017-2018) felt entirely free to say what they thought. There is a wide range of daily and weekly newspapers, as well as a vibrant private press. Radio is the most popular medium, particularly in rural areas. The government-owned radio network includes multiple stations, while there are also several dozen private radio stations and a few community radio stations. Most of the private radio networks are religious stations (33; 30 Christian and 3 Muslim; HAAC, 2017). Moreover, there are two state-owned and five private TV stations that regularly broadcast news. In addition, a number of foreign stations can be followed freely. Facebook (830.000 subscribers end of 2017, 35.6\% penetration rate) Twitter and other social media networks are increasingly used both by the government and the opposition. Internet access is improving, with $17 \%$ of the population with regular access to the internet in December 2017, compared to $2.4 \%$ of the population in 2008. Nevertheless, the penetration rate is well below the African average of $21 \%$. Furthermore, the mobile phone user penetration rate soared by $700 \%$ in the past five years from 2013 to 2018, with about $80 \%$ of the population using a mobile phone in 2018 (WB, 2018).

Freedom of speech and freedom of the press are guaranteed by law, but the law is not always respected. The High Authority of Broadcasting and Communications (HAAC), meant to protect press freedom and to ensure basic ethical standards, is heavily biased in favour of the government, notably during election campaigns. The parliament passed a more restrictive media law on 19 February 2013 that would have given the HAAC greater power over media with sweeping powers of censorship. Although the Constitutional Court overturned some of the repressive amendments of the media law, the lack of press freedom remained a critique of national and international human rights bodies. A new penal code was adopted in parliament in November 2015. The union of independent journalists complained about the significant harsher sentences for reporting false news introduced by the new code, which the union considered an attempt to intimidate and suppress independent reporting and encouraging selfcensorship. Overall, Freedom House (2018) upgraded Togo's status, including freedom of press status, since 2014 from "not free" to "partly free", with an aggregate status of 47 (of 100).

On 2 February 2017 the HAAC shut down a private radio and a TV station, City FM and La Chaine du Future, both of the group Sud-Médias, for allegedly breaching licensing rules. One day later, a journalist was severely beaten-up by the gendarmerie and arrested because he was documenting an eviction in Lomé. Shortly later, the general prosecutor warned anyone reporting this case of the risk of criminal prosecution for disseminating false news. Early June the HAAC suspended the newspaper La Nouvelle for one month for breach of journalist ethics and warned journalists to 'shy away from publishing gruesome stories and images'. The HAAC statue did not provide any appeal possibilities for these decisions. According to AI, the criminalization of the media created a climate of fear and self-censorship and discouraged journalists and the civil society from criticizing HR abuses, notably on subjects such as corruption, the army, the President, and the President's family.

Increasing encroaching on internet media freedom, took various forms, ranging from subtly increasing regulatory powers over social media to country-wide internet shutdowns, e.g. to thwart huge anti-government demonstrations in early September 2017. Government interference with the internet and mobile phones was of special concern in view of the growing reliance on digital information and communication technologies (ITCs) in the context of participatory development approaches of international donor agencies. Therefore, the EIU democracy index 2017 (published 31 January 2018) ranked Togo media all in all as 
'unfree'. The World Press Freedom Index of the global media watchdog 'Reporters without Borders' ranked Togo 86. out of 180 countries, both for 2017 and 2018.

In June 2017, the French companies Téolis and GVATogo-Vivendi were awarded licenses as internet service providers in order to improve the low performance of Togo's internet and to end the duopoly of the state-owned operator Togo Telecom and the privately owned Café Informatique. A national broadband infrastructure had already been established to connect public buildings in Lomé and Kara (Northern Togo) by a $250 \mathrm{~km}$ fibre optic network. Affoh Atcha Dedji, a member of the direction of UNIR and deputy of Tchamba, a henchman of Faure Gnassingbé, was nominated DG of Togocom, a new body formed by the fusion of Togo Télecom and Togocel at the end of the year. The Togocom was till then 100\% state-owned, but the parliament voted on 15 November 2018 to open up the three subsidiary companies TOGOInfraCom, TOGOServiceCom and TOGOInstalCom for a public-private partnership up to end of mars 2019. Togocom's president was another partisan of the Faure Gnassingbé, Colonel Dokisime Gnama Latta, a Kabyé and former minister of security in the cabinet (2012). Thus, the control of electronic communication channels remained firmly in the hands of the securocrats of the regime.

\section{Q3 | Rule of Law}

\section{Q3.1 | Separation of powers}

The constitution of 1992 established the legal framework for a presidential multiparty system in Togo. The president is elected for five years and cannot be challenged by the legislature (excluding extraordinary circumstances, such as abuse of office or illness). In a 'constitutional coup' at the end of 2002, a majority of the then ruling party, the RPT (which had secured power through rigged elections), in parliament voted for constitutional change in order to guarantee the continuity of the political power of the Gnassingbé clan in three crucial domains. First, it changed article 59 of the constitution to allow for a third consecutive presidential term. Second, it revised article 62, which in its new version reduced the minimum age of presidential candidates from 45 to 35 years, to allow the candidature of Faure Gnassingbé, the young heir to the throne of his father. Third, it effectively excluded the major opposition candidate, Gilchrist Olympio, from the electoral process. The latter stipulation, which still prevented the opposition leader to participate in the 2007 legislative elections, was eliminated by the new electoral law of August 2009. In addition, the new electoral law of August 2009 introduced a single run, first-past-the-post -system which provides the incumbent with a comfortable advantage vis-à-vis any challengers. The new procedure is unusual and problematic due to prevailing political conditions in Africa. The first-past-thepost system involves one round of voting, after which the leading candidate is declared the winner regardless of whether he has secured an absolute majority or not. This eliminates the opportunity for opposition candidates to re-group for a run-off vote.

The prime minister is nominated by the majority group in the unicameral parliament and appointed by the president. However, a great deal of power is invested in the office of the president, which makes it difficult for the other sections of government to serve as a counterbalance. The legislature, in particular, needs much more technical and constitutional authority and capacity if it is to successfully act as a check on the president's power. In addition, the corrupt judiciary has yet to live up to its constitutional role. The referendum on the government's proposal of a constitutional reform scheduled for 16 December 2018 and meant for reconciliation with the opposition, was cancelled without reason and prior notice. 
An independent judiciary does not exist. The Supreme Court and Constitutional Court, the latter inaugurated only in 1997, are dominated by members loyal to the Gnassingbé clan and the ruling party, as demonstrated by various biased decisions relating to recent elections. In September 2014, the head of state and the UNIR majority in parliament, boycotted by the opposition, re-installed the majority of the notorious Constitutional Court judges that had been already chosen in 2007, including its president Abdou Assouma. There is a sharp discrepancy between the constitutional law and its implementation. A separation of powers between the judiciary and executive branches (attorney and police) is rudimentary. The president of one of the Judges' Professional Association (l'Association Professionnelle des Magistrats du Togo, APMT) complained at the association's 2008 plenary that the Togolese people have to suffer from a two-speed judicial system, one for the poor and another one for those who are able to buy the judges' decisions. This holds up to date. A World Bank survey of businesses (2010) revealed that $60 \%$ of respondents believed that the courts were neither impartial nor free from corruption. Moreover, it is necessary to belong to the ruling party's inner network to be nominated for any influential position in the judiciary. On 3 November 2018, the General Assembly of Togolese magistrates during its meeting in Soutouboua founded its proper association, the Union Syndicale des Magistrats du Togo (USYMAT) presided by Adamou Békéti. A lively controversy on social networks in August had preceded the birth of the USYMAT. It was created in order to overcome the lethargy of the two existing professional organisations, the Professional Association of Magistrates of Togo (APMT, said to be close to the ruling regime) the National Association of Magistrates (ANM, supposedly close to the opposition). The USYMAT's objective was to revitalize the corporation of judges and better defend their material and moral interests. Apparently, it had little confidence in the independent functioning of the Superior Council of the Judiciary (CSM), responsible officially for managing the discipline and career of magistrates. The CSM members are elected for a four-year term. The 5th term of office of the CSM took office on October 23, 2015, the next elections will be held no later than the end of July 2019. The CSM was severely criticized by the judges themselves because the nomination of members, as well as their promotion and assignments, were apparently dominated by the same 'political-financing network' that dominated all public institutions in Togo (KAS, 2017).

Apart from that, the judicial system suffers from legal pluralism, i.e. the separation of official and customary law derived from colonial times. The majority of poor people have limited recourse to official law in actual practice. Traditional chiefs are considered brokers between the state and local populations and are recognized as custodians of customary law (droit coutumier) by constitutional stipulations. However, many of traditional chiefs have been discredited by decades of compliance with the autocratic Gnassingbé regime (see Q 5.2). In addition, the conservative and patriarchal structures of the chefferie, in general, counteract the devolution of power to the local people as well as gender equality. This holds especially for land-related conflicts, that constitute more than $70 \%$ of all pending cases. A new land code was adopted on June 5, 2018, aimed at making land transactions saver, to deal with multiple registrations of one land, construction in flood-prone areas, and to tackle land speculation and expropriation.

Q3.3 | Prosecution of office abuse 
There exists a long-standing culture of impunity vis à vis human rights abuses of the security forces. Abuse of public office is still endemic in Togolese society, and the embezzlement of public funds remains rampant. However, the political opening has meant that corrupt officeholders are subjected to somewhat more (negative) publicity. Nonetheless, due to the judicial system's shortcomings, these officials are rarely prosecuted. Although Amnesty International (AI) recognized slight improvements relating to human rights the culture of impunity still prevails, notably concerning security forces (ai, 2018), trafficking and moneylaundering (see Q15.3). The regime delayed the implementation of most of the recommendations for judicial reforms made by the CVJR in 2012. The National Human Rights Commission ('Commission Nationale des Droits de l'Homme', CNDH) complained of a lack of resources and of the government's unwillingness to cooperate, although a bill to improve the composition and organization of the $\mathrm{CNDH}$, particularly with respect to the prevention of torture, had been adopted in parliament already in mid-October 2015 .

\section{Q3.4 | Civil rights}

Although the civil rights situation in Togo has improved substantially, serious problems persist. Serious human rights issues included arbitrary deprivation of life, the use of excessive force by security forces, lack of due process, harsh and life-threatening conditions in prisons and detention centers, arbitrary arrest, executive influence on the judiciary, government restrictions on freedom of assembly, corruption of officials, criminalization of same-sex sexual conduct, although not enforced, and trafficking in persons (US Gov, 2017). Human trafficking concerned especially children, both internally and across the borders e.g. to Nigeria and Gabon. Children in Togo are engaged in child labour mainly in agriculture but also in quarries and sand mines. Boys of some Koranic schools known as talibés were forced into begging. The worst forms of child labour, including in forced domestic work, were also a result of human trafficking. In 2017, authorities identified 126 victims of trafficking, compared to 99 child victims identified during the previous reporting period. For the first time in over five years, law enforcement officials identified also four adult victims (US Gov. 2018 Trafficking in Persons Report). The new Penal Code of 2015 increased penalties for human trafficking and established penalties for the worst forms of child labour. However, the government did not devote sufficient resources to combat child labour, and the enforcement of laws related to child labour remained weak. In April 2018 the UNODC, in cooperation with the Togolese government, organized a series of workshops in the town of Kpalimé for judges, policers and other officials to upgrade their knowledge on trafficking of persons and the relevant stipulations of the new penal code of 2015. Kpalimé in South Western Togo and its border region to Ghana was considered to be one of the principal zones of destination of internal human trafficking.

Most Togolese rely on informal institutions of justice. They do not have access to the national judicial system because they are too poor and powerless. However, even the handling of the customary law by traditional authorities, many of them hand-selected by the ruling regime, corresponds all too often to the interest of the local power elite.

Deplorable prison conditions gained international attention. There were 4,859 prisoners and pretrial detainees (including 156 women) in 13 prisons and jails designed to hold 2,720, according to a 2017 U.S. State Department Human Rights Report for Togo. On 8 January 2019, the President granted a presidential pardon to 454 prisoners, including 177 persons in Lomé, 58 in Kpalimé, 38 in Aného, 35 each in Sokodé and Atakpamé, 25 in Dapaong, 15 in 
Basar, 13 in Kara, 9 in Mango, 8 in Vogan and 6 in Kanté. However, the political prisoners were not released.

The police and gendarmerie were reported to regularly use torture to extract confessions. Plagued by corruption, strong executive influence and lengthy pre-trial detention periods, the judicial system functions poorly. Civil rights for a number of groups are restricted.

Violence against women and the practice of female genital mutilation continues, though on a diminishing scale, last but not least, because of donor-assisted awareness campaigns. Female genital mutilation was formally outlawed in 1998 and has decreased by more than halve since 1996. However, the practice of female genital mutilation still exists on a considerable scale. The prevalence of FGM in women aged 15 to 49 on a national scale is $4.7 \%$. The region with the highest prevalence is Centrale, at $17.4 \%$; the lowest is Maritime in the south, at $0.4 \%$ (' 28 Too Many', 2018). The prevalence of excision decreases with women's age, ranging from $10.2 \%$ among women aged $40-45$ to $0.3 \%$ among girls under age 15 , according to Togo's third Demographic and Health Survey of 2013. The prevalence of childhood marriage (before age 15) also declined, ranging from $11.1 \%$ among women aged $45-49$ to $1.9 \%$ among those aged 15-19 (Afrobarometer, 2018).

Togo has ratified most international human rights treaties and it is a member of the U.N. Human Rights Council for the period 2016-2018. Nevertheless, important omissions still remain. By the end of February 2014, the U.N. Human Rights Council encouraged the government to endorse U.N. treaties not yet ratified, including the Rome Statute of the International Criminal Court (ICC), still not endorsed end of 2018. Following the first Universal Periodic Review (UPR) at the U.N. Human Rights Council (Geneva) in 2011, Togo submitted its second national report on 17 August 2016. The UNHRC working group on the UPR adopted its report on 4 November 2016, proposing a further 136 recommendations for the improvement of human rights and the rule of law in Togo. The UN-HRC summarized the outcome of the universal periodic review on 16 March 2017 with the opaque formulation that 'questions or issues (were) not sufficiently addressed during the interactive dialogue held in the Working Group'.

\section{Q4 | Stability of Democratic Institutions}

\section{Q4.1 | Performance of democratic institutions}

Formal political institutions are only partially democratic and their performance remains deficient. The president's conduct of office shows more transparency and commitment to dialogue than has been the case during his father's regime. The question is whether his efforts are sincere and stable given that President Faure Gnassingbé is still surrounded by many figures of the old dictatorial regime. Whereas parliament now engages in controversial debates, its deputies often lack professional depth of knowledge. This is due, on the one hand, to the legislature's insufficient working conditions and, on the other hand, to the fact that the opposition has yet to move beyond criticizing the government and to formulate alternative policy proposals. Judicial reform is underway, but the aforementioned challenges (see 'independent judiciary') persisted throughout the assessment period. In Freedom House's 2018 Freedom in the World rating, Togo's overall status remained 'partly free' as in the previous two years. However, In the Economist Intelligence Unit's democracy index 2017 (published 31 January 2018), Togo was downgraded from rank 130 (2015, 3.32 of 10 points) to rank $142(2017 ; 3.05)$ out of 167 countries, mainly due to its encroaching on media freedom, including wholesale internet (WhatsApp, Facebook, Twitter) and mobile-net shut- 
downs to counter anti-government protests. EIU classified Togo as an 'authoritarian regime' as before. As consequence, Togo's population became increasingly frustrated by the regime's inability to initiate meaningful reforms.

\section{Q4.2 | Commitment to democratic institutions}

The commitment to democratic institutions has obviously increased in the wake of the political opening and continuing pressure of international donors. Apparently, the Gnassingbé regime has learned from the past, as indicated by the formal rupture with the legacy of the former unity party RPT and its replacement by a modernized conservative party UNIR in April 2012. The regime was eager to strengthen the legitimacy of its irregularly acquired grip on power through peaceful although not democratic legislative $(2007,2013,2018)$ and presidential $(2010,2015)$ elections. However, as far as the existing institutions are concerned, a high degree of scepticism remains, since the president was not elected democratically and parliament, still dominated by the RPT/UNIR, has not shown its real potential yet. The personality cult around the president is still present in daily life. All this, together with the unpredictable attitude of the hardliners within the RPT/UNIR and the security forces, raises further doubts about the level of commitment to democratic institutions.

\section{Q5 | Political and Social Integration}

\section{Q5.1 | Party system}

Although there exist 113 (2018) political parties in total, Togo is de facto heading towards a two-party system, involving the ruling Union for the Republic UNIR party, and the National Alliance for Change (ANC) (l'Alliance Nationale pour le Changement) which split from the UFC (l'Union des Forces de Changement) during the schism within the major opposition party following the lost presidential elections of 2010. The dissolution of the ruling RPT, the former socialist unity party founded in 1969, and creation of a modernized party UNIR in April 2012 was the response by the ruling party to adapt to the requirements of a modern multiparty system. This has induced a gradual democratization of party processes and renewing of party members. However, the informal personalized party structures remained pretty much the same. On 26 May 2010 the veteran leader of the UFC, Gilchrist Olympio, whose hopes of becoming president were declining due to his advanced age, surprisingly agreed to join a 'government of national recovery'. This constituted a landmark in Togolese politics, in view of the bitter generation-long rivalry between the Olympio and Gnasssingbé families. However, the reconciliation between RPT/UNIR and UFC resulted also in a considerable weakening of the opposition.

The opposition split between a 'radical' and a 'moderate' wing, labels which were originally attributed by the government in the 1990s, with moderates more willing to cooperate with the government. The 'radical' wing, represented in parliament as well, is the Let's Save Togo Collective (Collectif Sauvons le Togo, CST), which was founded in April 2012. CST is composed of political parties and civil society organizations led by the National Alliance for Change (Alliance Nationale pour le Changement, ANC). Shortly afterwards, in August 2012, a confederation of smaller moderate opposition parties ('Comité d'Action pour le renouveau' (CAR), 'Sursaut National', etc.) joined the foundation of a rainbow coalition, Arc-en-ciel. The extra-parliamentary opposition embraces the 'Nouvel Engagement Togolais' (NET), 
'Organisation pour Bâtir dans l'Union un Togo Solidaire' (OBUTS), 'Parti National Panafricain (PNP)' and over 80 other smaller parties. In November 2014 the major parties of the radical and moderate opposition united in an opposition coalition named Combat for Political Change 2015 (Combat pour l'alternance politique en 2015, CAP 2015) that chose Jean-Pierre Fabre, the leader of ANC, as the sole candidate for the 2015 presidential election. However, with the defeat of Fabre CAP 2015 lost its significance.

In response to the unyielding attitude of the government and the inconclusive negotiations with the divided opposition, forces of the 'moderate opposition' created in January 2017 a new informal opposition coalition composed of six smaller opposition parties, of which only two were represented in parliament, i.e. ADDI (Alliance of Democrats for Integral Development) and FDR (Democratic Forces for the Republic, an elimination of the former opposition party CAR). This informal coalition wanted to bridge the political stalemate between the major 'radical' opposition coalition CAP 2015 and the smaller 'moderate' opposition coalition Arc-en-ciel (CAEC) on the one side and the ruling party UNIR (Union pour la Republique) on the other. However, this exercise was unsuccessful too.

Yet, six months later, in August 2017, an hitherto hardly known opposition party, the Parti National Panafricain (PNP), founded in 2014, thoroughly shuffled up the encrusted domestic politics in organizing huge demonstrations of all the 14 major opposition parties (CAP 2015, group of 6 'moderate' opposition parties (arc-en-ciel), CAR, PNP, Santé du people). This was facilitated by a new approach to politics of PNP's charismatic leader, Tikpi Atchadam, a former student leader at the University of Lomé and 50-year-old lawyer from profession, who originated from the Tem (Kotokoli) people of Kparatao, a village $7 \mathrm{~km}$ from Sokodé, Central Togo. His use of modern technics of diffusion of his message, like WhatsApp as well as DVD copies of his strong speeches, distributed up to the most remote villages, contributed to his success. He motivated the discontented with his outspoken language to come out en masse and to demonstrate for a speedy end of the autocratic reign of the Gnassingbé dynasty. In August 2017, the most important 14 opposition parties united to a common front, called 'C14'. Big anti-government marches with over 100,000 participants (according to amnesty international) in Lomé on 6 and 7 September 2017 aroused special attention. This all the more since social network organization had been systematically hindered by the government that had blocked access to WhatsApp, mobile phone and internet.

The party system still mirrors to a considerable extent regional and ethnic divisions. Thus, political parties tend to have readily identifiable ethnic and regional bases. The RPT/UNIR party had greater representation among northern ethnic groups than among southern groups, while the reverse was true for the ANC and CAR opposition parties. The 2015 presidential election had reaffirmed this trend. Last, but not least, the Togolese diaspora (estimated at $2 \mathrm{~m}$ people) could play a decisive role in domestic politics if it would be allowed to vote, as the opposition demands since several years, recently supported by the ECWAS consultation group in 2018. The government promised to inscribe the right into the new electoral law, following the example of Burkina Faso, Mali and Senegal, were between 200,000 and 265,000 additional voters outside their national territory had been mobilized already. The Côte d'Ivoire too shall authorize their $3 \mathrm{~m}$ citizens living in the diaspora to vote in the next presidential elections in 2020 . 
There exists a broad range of interest groups. The most influential Christian churches and the two Muslim organisations Union of Muslims in Togo (UMT, founded in 1964) and the Association of Muslim Executives of Togo (l'Association des Cadres Musulmans du Togo, ACTM, founded in 2003) exert a mediating and constructive political influence which has been recognized far beyond their own followers. Earth priests (chef de terre) and traditional chiefs still wield a strong influence at the local level. Their role as guardians of tradition and customary law, as enshrined in the constitution, had meant to be determined by the national decentralisation program (Programme National de Consolidation de la Décentralisation, PNCD) initiated by the government in 2004. Although the first comprehensive decentralisation law was adopted as early as 1998 it had never been applied. The 2007 law on decentralisation replaced the 1998 legislation, but again the process stalled. In 2016 the government defined the role of the traditional chiefs in the decentralisation process in more detail (décret $\mathrm{n}^{\circ}$ 2016-028/PR du 11 mars 2016 portant modalités d'application de la loi $\mathrm{n}^{\circ}$ 2007-002 du 08 janvier 2007 relative à la chefferie traditionnelle et au statut des chefs traditionnels au Togo.).Yet, the political crisis of 2017 showed that the traditional chiefs were still entangled to such extent with the Gnaissingbé regime which had manipulated and instrumentalized them since generations that they did not dare to take position in the actual crisis, contrary for example to the Christian bishops, the CSOs or the traditional chiefs in Burkina Faso who had thrown all their moral authority into the balance for the solution of the socio-political crisis in Burkina in 2015.

Student organizations consider themselves the political avant-garde and act accordingly. Until 2006, most of them were intimately linked to the ruling party. Thus, the High Council of Students' Associations and Movements (HaCAME) degenerated into a pro-government militia which actively supported the incumbent's bloody 'enthronement' in 2005. Since 2011, oppositional student organizations have come to the fore, staging periodic anti-government demonstrations in the universities of Lomé and Kara. Their leaders have suffered political persecution. In July 2017 the HaCAME opposed the competing Togolese League of Student Right's (Ligue Togolaise des Droits des Etudiants, LTDE) vainly call for an exam boycott. On that occasion, it set up a second office at the University of Kara beside the headquarters in Lomé. In addition, there exist numerous professional representations of traders (e.g., the renown female cloth traders of Lomé, 'Nana Benz'), farmers, lawyers and judges. However, most of them are either biased and closely linked to the former unity party RPT/UNIR or they have little political influence. Although there are a large number of labour unions in Togo, none of them has the strength or capacity to significantly influence the policymaking process. The unions nevertheless succeeded in convincing the government to continue paying subsidies for fuel, some staple foods and fertilizers so as to avoid a serious social crisis.

With the democratic renewal of the early 1990s civil society organizations (CSOs) mushroomed. According to informed estimates there existed about 2,000 CSOs already in 2012, of which just 325 were officially registered NGOs. Since 1986, the government has promoted its federation within FONTGO (Féderation des Organisations NonGouvernmentales au Togo, 150 members in 2018). However, some of the most credible NGOs are not represented by this federation. Therefore, two concurrent umbrella organizations have been formed in 1996, the UONGTO (Union des ONG du Togo, 124 members, 2018) and in May 2012 the umbrella organization FNRRT (Fédération Nationale des Réseaux Régionaux du Togo). Many, CSOs are covered job and income-generating organizations of their founders (so-called 'ONG-valises'). Their activities are mostly focused on Lomé and Togo's southern regions. Their target-groups, especially the poor and underprivileged, including women, are rarely allowed adequate rights of participation or selfdetermination. However, there exist a handful of CSOs that are influential, viable and 
independent and operate nationally. These include ACAT-Togo (Action des Chrétiens pour l'Abolition de la Torture), which won the French Republic's human rights prize in 1997, the HR organization LTDH (Ligue Togolaise des Droits de l'Homme) and the GF2D (Groupe de Réflexion et d'Action Femmes, Démocratie et Développement) concerned with gender rights and impunity. Some of these organizations co-operate with political parties in broad antigovernment movements, such as CST. In June 2017, the Union of Municipalities of Togo (L'Union des Communes du Togo, UCT) organised the vocational training of municipal and prefectural officials in preparation of the decentralisation process.

\section{Q5.3 | Approval of democracy}

$\mathbf{n} / \mathbf{a}$

According to a representative survey of Afrobarometer published in 2018, 75\% affirmed that democracy would be the best of all forms of government, against just $8 \%$ who thought that a non-democratic government would be preferable under 'certain conditions'. However, $47 \%$ of respondents held that the last presidentials of 2015 were not free and transparent or had major faults. Just $13 \%$ of interviewed persons (2017-2018) felt 'entirely free' to say what they thought, and 26\% 'quite free'. Nonetheless, 54\% thought that their personal liberty to express their view has increased during the past years. Yet, $80 \%$ confirmed that they wanted to be able to join whatever organisation - even those that oppose government policy - whether the government approved it or not. Last, but not least, $87 \%$ of respondents "agreed" or "strongly agreed" that there should be a two-term limit on the presidential mandate (which is not in effect). Apart from the Afrobarometer survey, no independent opinion polls are conducted in Togo. However, there is convincing additional anecdotal evidence that people indeed want a democratic system. This desire, however, does not so much express a reflected and informed approval of democratic principles and procedures than the profound desire for change. Whereas, the high level of participation $(85 \%)$ at the legislative elections of 2007 can be interpreted as an indication of the population's clear commitment to take part in building their democracy, the relative low turn-out of $61 \%$ and 59\% during the presidentials of 2015 and the legislative elections of 2018 respectively was interpreted as a sign of general disappointment of the opposition with the biased organization of the electoral process. This was confirmed by considerable regional variations in voter turn-out, for example with $70 \%$ to $90 \%$ in the northern strongholds of the ruling RPT/UNIR and far lower figures in the southern opposition strongholds during the 2010 presidentials. In the 2015 presidential turnout was initially estimated at about $53 \%$ nationwide, i.e. at least $10 \%$ lower than at the previous presidentials, but this was later adjusted to $61 \%$ without explanation. The fall in turnout compared with the previous polls was interpreted as a sign of growing voter fatigue, which may have been aggravated by the boycott called for by smaller opposition parties and a potentially high number of voters who could not cast their vote because of technical problems, especially in the Maritime region.

\section{Q5.4 | Social capital}

The history of informal political institutions in Togo shows the rich base of 'traditional' as well as 'modern' institutions, which participate actively at all levels of society. The most visible outcome of people's participation was the Sovereign National Conference of 1991 with representatives of all social strata of the nation. However, because the visions of this conference were dashed by the violent political oppression of the dictatorial Eydéma regime 
up to 2005, similar social initiatives were difficult to re-establish. On the base of the general Global Political Accord (APG) of 2006 the general public was again more inclined to feel free to associate, to express their views and to organize themselves for self-help efforts, in spite of the government's attempts to restrict association and assembly rights (see 'association and assembly rights'). There exists a variety of traditional associations (including a multitude of microfinance or credit institutions, see banking sector), trade unions, human rights, religious and media organizations as well as numerous local associations. Many of these self-help groups are based on traditional systems of mutual support, others have been stimulated by international NGOs, churches or the government (see "interest groups").

\section{Market Economy Status}

\section{Q6 | Level of Socioeconomic Development}

Q6.1 | Socioeconomic barriers

Although the current socioeconomic situation in Togo remains precarious, it improved considerably over the past decade. Thus, Togo's HDI trend progressed over the past three decades from 0.4 in 1990 to 0.5 in 2017. Nevertheless, Togo was still ranked at the bottom (rank 165) of 189 countries surveyed in 2017. The HDI of 0.503 was also below the average of 0.537 for Sub-Saharan countries. Other African countries which are close to Togo in HDI rank and in population sizes, such as Benin and Rwanda, ranked 163 and 158 respectively. The overall trend was reflected too by the UN World Happiness Report of 2018 where Togo with 1.2 points was the largest gainer since 2008-2010, compared with 2015-2017. It had been the lowest ranked country in World Happiness Report 2015 and now ranks 17 places higher. Nevertheless, it ranked still at the bottom (139) out of 156 countries evaluated.

Despite strong agricultural production, economic growth was estimated to have fallen from $5.1 \%$ in 2016 to $4.4 \%$ in 2017 . The socio-political tensions in the aftermath of huge violent anti-government demonstrations in August 2017 were increasingly taking a toll on economic activities. The turnover of large companies, notably in the Tertiary sector has fallen. Private sector credit during the second half of 2017 was lower by $4.2 \%$ relative to the first half of 2017; the largest decline was in the construction sector (IMF, 2018).

Moreover, growth was not inclusive. Poverty remained at a high level, with $55.1 \%$ of the population living below the poverty line in 2017 (AEO, 2018; GNI per capita 1,620 intern. \$, PPP-2017), Though the poverty rate decreased since 2011 (59\%; QUIBB 2015). However, according to the latest available figures, the depth and severity of poverty worsened, with about $80 \%$ of the population now at risk of falling below the poverty line. The rate of extreme poverty (49.2\%) in Togo was almost twice the poverty rate in Ghana $(25.2 \%)$. The National Fund for Inclusive Finance (Fonds national de la finance inclusive, FNFI), created in 2014, disbursed credits of about US \$ $134 \mathrm{~m}$ in the four years of its existence to the target-groups, i.e. the poor and low-income persons. However, the FNFI will have to rely from 2019 onwards on public-private partnerships because the government decided to stop financing.

In addition, there was an alarming variation in poverty between the so-called leading and lagging areas of Togo, according to a WB publication on the geographical concentration of welfare, published in November 2017. Nine out of 36 prefectures counted among the leading 
regions: Togare Bassar, Cinkassé, Danyi, Golfe, Lacs, Lomé, Ogou, Tchaoudjo, and Vo. Poverty in the far North of Togo was up to three times as high as in the South. Poverty rates observed varied between $15 \%$ in the top three prefectures (Golfe, Lacs, and Lomé) and more than $90 \%$ in the bottom three (Tandjoaré, Akebou, and Doufelgou). The largest poor population was concentrated in Oti prefecture, the most disadvantaged area in terms of income. Moreover, about half of Togolese people had neither access to pipe born drinking water nor to electricity (rural population's access to electricity with $20 \%$ even less), and the country had just one doctor per 14,500 inhabitants (AEO, 2018).

In addition to the regional-, the inter-household income inequality was increasing. The Gini coefficient for Togo increased from 0.34 in 2013 to 0.43 in 2017 nationwide (HDR, 2018). The rural exodus continued. About $40 \%$ of the population live in urban areas, an increase of 160\% between 1990 and 2014 (AEO Togo, 2016). The inequality is more pronounced in urban centres than in the countryside. Urban unemployment and underemployment persist, with an estimated $33 \%$ of the urban population either unemployed or underemployed. Official rates of unemployment $1.8 \%$ (HDR, 2018) are questionable.

Discrimination against women is widespread, but decreasing gradually (see "Equal opportunities"). Available figures concerning the prevalence of HIV are only estimates, they varied from $2.3 \%$ to $3.6 \%$ of adults aged 15 to 49 in 2001 , decreasing to $1.4 \%$ to $2.1 \%$ of adults in 2017 (WDI, 2018). This decrease was partly attributable to the introduction of free anti-retroviral treatment in November 2008. End of 2017 there were 59,752 persons with HIV registered under treatment with the antiretroviral (ARV), i.e. a therapeutic rate of $57 \%$, as declared by the coordinator of the permanent secretary of the national council to combat AIDS and sexually transmitted infections (SP/CNLS-IST), Vincent Pitché, on 29 June 2018. According to him, Togo spends about US \$ $17.6 \mathrm{~m}$ p.a. since five years to combat HIV.

The subsistence economy in rural areas, the potential of the informal sector in urban areas, and remittances from expatriated Togolese (see Q17.1) have helped to avoid a more severe crisis. Last, but not least, Togolese citizens lack adequate freedom of choice and an effective decentralization policy including a real devolution of power and resources.

\section{Q7 | Organization of the Market and Competition}

\section{Q7.1 | Market-based competition}

Once euphemistically called the "Switzerland of West Africa", Togo today strives to transition from a low income, fragile state to an emerging economy. Yet, Togo still lacks the foundations for credible market-based competition and good governance, although there have been undeniable improvements.

Togo remains dependent on development aid, though net official development assistance received (current US\$) (millions) decreased substantially in the past decades from 258.2 in 1990 to 165.0 in 2017 (WDI, 2018). Europe (EU, France, Germany) is by far the biggest provider of development assistance, besides China. The EU approved disbursements of US\$ 16.5 bn in budgetary aid for Lomé in February 2017, which was complemented by a generous German aid package of $60 \mathrm{~m}$ US \$ (equally divided between technical and financial cooperation), signed during a five day visit ( 8 to 13 June) of the Togolese head of state to Berlin. This aid package corresponded to a $50 \%$ increase in aid since the last government negotiations in 2014. On 22 June 2017, the EU, France and Germany agreed in Lomé to harmonise their aid to Togo which amounted to about $715 \mathrm{~m} €$ in total for the period 2014 to 
2020. Therewith, Europe remained the most important partner of development cooperation with Togo. However, China follows suit. Togo has long-standing good relations with China since 1972. Sino-Togolese cooperation in recent years included infrastructure projects, like the stadium of Kégue at Lomé, the new international airport of Lomé, the new parliament building in Northern Lomé (inaugurated 14 June 2018), the big bypass road to link the harbour of Lomé directly to the Ghanaian border at Noépé (2018). The deep-water harbour of Lomé is an 'anchor-point' in China's ambitious Belt and Road initiative in West Africa. In addition, China provided for the construction of a modern TV-complex for the state-run Togolese television (TVT) and Radio Lomé. The controversial construction of the joint Benin-Togolese Adjarala hydropower dam on the Mono river at the joint border, contracted by the Chinese company Sinohydro and financed with credits of the China Exim-bank by an amount of $551.08 \mathrm{~m}$ US \$, which had been stalled in 2016 because of financial problems, continued. On 11 September 2018 the China-Africa Development Fund (CAD Fund) confirmed once more its commitment to continue financing the project. The start-up of the project was postponed to 2020 . It was meant to significantly increase electricity generation by 147 megawatts. However, environmental, economic and social impacts on the local population were a concern. Approximately 21,000 people will be affected on both sides of the border, including 12,000 people or 1,800 households in Togo. The five-year strategic action plan of the government for the electricity sector for the period 2018-2022 at the tune of $\mathrm{F}$ CFA 668bn (US $\$ 1.2 \mathrm{bn}$ ) aims to treble Togo's generation capacity of $161 \mathrm{MW}$. Apart from the Adjarala dam, the plan envisages the construction of three hydropower plants with a total capacity of $64.1 \mathrm{MW}$. The largest is the Sarakawa plant in northern Togo, at a total estimated cost of F CFA 39.6bn, and the Titira hydropower plant (F CFA36.2bn) on the Kéran River, both with a capacity of $24 \mathrm{MW}$. However, since the reservoir of the latter will be in Benin, the project will require close coordination with the Benin authorities. The third plant will be built on the Mono River at Kpessi, with a capacity of 15.9MW and cost of F CFA28.6bn. Other planned generation projects include the construction in two phases of a 50MW solar photovoltaic power plant (F CFA32.5bn), and the construction of a 65MW thermal power plant (F CFA52bn), as well as additional thermal capacity totalling 50MW and costing CFA40bn. More than half of the total investment should go to new generation capacity, while nearly 25\% (F CFA155bn) will be earmarked for new transmission and distribution lines, especially in the Greater Lomé area. Another F CFA67m will be spent on distribution of solar home systems in rural areas, in a program in cooperation with BBOXX (see below). The government expects the strategic action plan to be financed to $51.9 \%$ by the Agence Togolaise de l'Electrification Rurale et des Energies Renouvelables, to $28.7 \%$ by public-private partnerships (PPP), $9.8 \%$ by the CEET. Moreover, it counts on multilateral donors such as the European Union, the World Bank and the African Development Bank for the remaining 9.6\%. The World Bank executes with funding from the German KfW and European Investment Bank a project to strengthen power transmission between Togo and Benin. The German technical cooperation (BMZ) finances activities of its implementing organization GIZ to strengthen the capacity of the West African Power Pool. In addition, BMZ provides funds for the KfW to rehabilitate the hydropower plant in Nangbeto. KfW is also financing the transmission line between Sakété and Porto Novo. On behalf of six donors, the Energising Development Program (EnDev) executed by GIZ is supporting grid extension, grid densification, picoPV system and dissemination of improved stoves.

End of 2017 (22.12.), the AfDB provided an additional $11.4 \mathrm{~m} €$ under the Agribusiness Promotion Support Program (PAGAP) meant a. o. to improve conditions for inclusive growth, the development of agribusiness, the reduction of the agricultural trade deficit from $\mathrm{F}$ CFA 64 bn to $30 \mathrm{bn}$, and the improvement of the tax burden ratio from $16.7 \%$ (2016) to $21 \%$ of GDP in 2018. 
Togo's World Banks Doing Business indicator improved little over the past ten years. In 2009, Togo was one of the worst performing economies ranked 166 out of 183 economies. Although in 2018 it improved to rank 156 of 190 economies worldwide (WB, 2018), it recorded for the past two years a slight deterioration for Togo from rank 154 (2017) to 156 (2018), both well below its peers in the WAEMU region and the Sub-Saharan average. As in the case of five other members of the West African Economic and Monetary Union (WAEMU / UEMOA), which equally ranked at the bottom, Togo's political and administrative operating environment constituted a barrier to the growth of private direct investment and private sector activities. The most significant improvement in 2016/17 was Togo's improved access to credit information by launching a new credit bureau (WB, 2018). Major deficiencies in property registration (rank 182 of 190), tax paying (rank 173; high taxes and costly customs procedures), enforcing contracts (rank 143), and protecting investors (rank 146) impeded FDI. However, over the past decades foreign direct investment (FDI), net inflows (BoP, current US\$) (millions) improved steadily, from 18 in 1990 to 146 in 2017. The allocation of foreign aid is crucial for investments in the country's neglected infrastructure. Regulations on the labour market make flexibility in staff management difficult, especially when starting a new business. The non-salary cost of employing workers is high, and it is almost impossible to dissolve contracts without legal consequences. In addition, there is little flexibility in working hours as provided by the law. Economic Freedom, as measured by the Heritage Foundation's Economic Freedom Index 2018, published in November 2017, decreased nevertheless from rank 137 (2016) to 144 (score: 67.2, 2018) of 183 countries surveyed. In short, Togo's economic freedom too remained with the overall status of 'mostly unfree'.

In summary, Togo's political and administrative operating environment constituted a barrier to the growth of private direct investment and private sector activities. A thorough reform was prevented by vested interests, lacking administrative and judicial transparency and widespread corruption.

\section{Q7.2 | Anti-monopoly policy}

Key sectors of the economy, notably the banking, cotton and phosphate sector, are still in the hands either of a few individuals or parastatal. The electricity sector is still characterized by high costs and limited penetration. The Compagnie Energie Electrique du Togo (CEET), created in 1963 is a state monopoly company that provides electricity to about 166000 clients (CEET 2018). The CEET is mainly a distribution company, purchasing 50\% of its electricity from the joint public Benin/Togo Generation and Transmission Power Utility (Communauté Electrique du Benin, CEB), and 50\% from Contour Global, a private power producer. In June 2016, the parliament adopted a law authorizing the ratification of the international BeninTogolese accord of electrification, which ended the monopoly of the CEB on the purchase of electric power as a sole buyer and opened the market to competition. However, CEB retained its monopoly on purchases of energy imports for its own sources of production and transportation. Further privatization and adequate steps to attract foreign and domestic private investment are part of a strategy to stabilize macroeconomic stability and growth, but they have still to be put into practice. Privatization of the state-owned banks was further delayed (see Banking System). Reforms of the mining, telecommunications and energy sectors progressed slowly under resistance from vested interests (IMF 2016). The mining industry has the potential to develop into one of Togo's largest economic sectors, with the country being the world's fourth-largest phosphate producer. Togo's estimated 60 million metric tons of 
phosphate reserves have the potential to give this industry a boost. Phosphate production, the major export industry, which had been nationalized under late Eyadéma Gnassingbé (the father of Faure) in 1974, was boosted in 2017 by the completion of a $1.4 \mathrm{bn}$ US $\$$ project to mine $5 \mathrm{~m}$ tonnes per year of phosphate rock. The production was managed by the Société Nouvelle des Phosphates du Togo (SNPT), a public-private venture (60\% state- and 40\% private-owned), supplemented by the construction of a phosphoric acid and fertiliser plant, built by Elenilto, an Israeli mining company. However, the SNPT apparently underperformed because of large-scale corruption. An independent consultant, Dr Thomas Koumou, who had investigated the case, estimated the loss of revenue for the Togolese public treasury at F CFA 215 bn (US\$ $371 \mathrm{~m}$ ) between 2005 and 2010, according to disclosures of the NGO Business Intelligence ('Veille Économique') in January 2018. According to revelations of the African Investigative Publishing Collective (aipc, Accra) in 2017, phosphate production was informally administered directly from the offices of President Gnassingbé by the MoroccanIsraeli family of Raphael Edery, who collaborated under direct orders of the President with his son Liron, who resided at the headquarters of the SNPT in Paris. Evidence suggested that this special arrangement was liable to support corruption. In 2016 and 2017, for example, close to $90 \%$ of Togo's phosphates had been bought $20 \%$ below world-market prices at US\$ 100 per tons by 'privileged clients', i.e. the Indian family of shippers Gupta-Kalyan. Ashok Gupta had been already under investigation by the Australian Federal Police in another case for bribing of politicians in exchange for the phosphate resources.

In July 2018, the government concluded a contract with the English enterprise Bboxx to provide 300,000 domestic solar-home-kits to be distributed in rural areas in the next five years within the framework of the CIZO (enlighten, in Mina, the local language) initiative at an estimated cost of about 117 m US\$ (see Q13.19. Thereby, the electrification rate in rural areas was meant to rise from the present $6 \%$ to $35 \%$ in 2022 . The government was to provide about $15 \mathrm{~m}$ US\$, and $102.5 \mathrm{~m}$ US\$ will have to be secured from private investors, i.e. to be sold on a pay-as-you-go model using popular mobile payment solutions by the sale of the kits via mobile payments (PAYGO). In the pilot stage, the first 10,000 kits will be delivered for the rural areas within the next year, assisted by initial funding of about $1 \mathrm{~m}$ US\$ of the Sustainable Energy Fund for Africa (SEFA), a multi-donor trust fund administered by the African Development Bank.

\section{Q7.3 | Liberalization of foreign trade}

Foreign trade is liberalized in principle, but significant limitations persist. Togo's major agricultural exports are cotton, cocoa and coffee. These exports generate about $40 \%$ of export earnings, with cotton being the most important cash crop. Moreover, Togo is among the world's largest producers of phosphate. Re-exports are significant as well, as Togo is one of West African's most important transit-economies, along with neighbouring Benin. Therefore, foreign trade is decisive to Togo's economy. The combined value of exports and imports of the so-called entrepôt trade (legal transit and mostly illegal re-export/smuggling combined) amounted to $105 \%$ of GDP (Heritage 2018 Index of Economic Freedom). It consisted mostly of petroleum products (from Nigeria), cotton from Burkina Faso and used cars (from Europe). The unofficial entrepôt trade contributed to a culture of corruption and tax evasion. Trade freedom scored better with 67.2 of 100 points, compared with investment- and financial freedom of 65.0 and 30.0 respectively, according to the 2018 Index of Economic Freedom of the Heritage Foundation. Overall economic freedom decreased by 5.4 points, with a steep decline in fiscal health and judicial effectiveness. Togo scored $47.8(53.6,2016)$ out of 100 points, and ranked at the bottom of 168 out of 178 economies worldwide, and $41(29,2016)$ 
out of 46 economies in sub-Sahara Africa. Thus, Togo's overall status remained "mostly unfree". In 2015, Togo ratified the WTO free-trade agreement, with a third of the LDCs having now signed the treaty. Togo has four Export Processing Zones (EPZ); three in Lomé and one in Kara, managed by the company SAZOF. Lomé's EPZ were created in 1989 with the aim to promote foreign trade and attract investments by granting benefits and privileges (tax, financial and administrative) to encourage participating companies to increase employment and value added in the country. In 2016, the EPZ comprised 57 operational enterprises and additional 37 in construction. These companies are from 13 different nationalities, while $29 \%$ belong to Togolese investors (valued at about US \$ 300). These companies provided over 13,000 full-time jobs, representing a significant proportion of employment in the formal private sector and exported US \$260m. In 2012, the EPZ accounted for more than half of Togo's exports, $80 \%$ of its products were sold in ECOWAS countries. However, domestic value added in the EPZ Lomé declined over time, from $51 \%$ of the turnover of companies in the EPZ in 2001 to $36 \%$ in 2008 and just $18 \%$ in 2012. The World Bank recommended a restructuration of the free zone in order to promote more labourintensive export industries. However, Togo's economy remains vulnerable to shocks to export demand.

In general, the weighted average tariff rate decreased from $15.87 \%$ (2008) to $9.51 \%$ ( 2014). freedom of trade was further restricted by non-tariff barriers of trade.

\section{Q7.4 | Banking system 5}

The banking system in Togo deteriorated since the early 1990s because of unprofessional government involvement in lending and banking decisions. As a consequence, the IMF has requested since 2007 a reform of the banking sector, including the privatization of government-run banks and an increase in bank capitalization. The system was then put under the scrutiny of the WAEMU. More than $30 \%$ of loans issued by these banks were considered to be non-performing and strained by bad loans from parastatals. The government wanted to privatize public banks by the end of 2010 . However, the privatization of the four public banks has been delayed due to the banks' weak finances and the unwillingness of the government to sell according to market conditions rather than in the interests of the Gnassingbé clan and its followers. The call of the IMF for privatization of the two remaining state-owned banks, the Bank for Trade and Industry (BTCI) and the Union of Togolese Banks (UTB), which had been opposed by the government for years, was finally heeded by the National Assembly on 16. November 2018, by authorizing the privatization. According to The IMF, further actions are needed to tackle vulnerabilities in other banks.

In addition to formal institutional banking, the microfinance system (systèmes financiers décentralisés, SFD) and informal traditional African saving and loans schemes (tontines, known as Adakavi in Togo) play an important role, especially for small and medium-sized enterprises (SME), notably in the informal sector. They carry usurious interest rates that range from $25 \%$ to $100 \%$ per months, i. e. $300 \%$ to $1,200 \%$ per year (Lelart, M. 1990). The members of these tontines often use social pressure to obtain loan repayments. In serious cases, the villagers take the property of the defaulter. In recent years, sex-Tontines spread at institutes of higher learning whereby female students organize themselves in rings of prostitutes and share their earnings. Their stakes start with F CFA 5,000F, some of the girls take double or even triple. Although the minister of Finance, Adji Otèth Ayassor, promised already in October 2013 to intervene against the illegal exploitation of microfinance 
institution, nothing happened up to now. However, the SME were aided by the African Guarantee Fund (AF West Africa) that declared in July 2018 to help the SME to gain access to bank credits to the tune of US $\$ 150 \mathrm{~m}$ for the next five years, by providing US $\$ 75 \mathrm{~m}$ guaranties for the banks and other financial institutions in Togo. Moreover, in August 2018 the Professional Association of Decentralized Financial Systems in Togo (APSFD-Togo) was founded with the aim to help the government to end the practice of illegal microfinancing. Mutual tontines had an estimated $2.4 \mathrm{~m}$ beneficiaries by end of June 2018 (BCEAO, 2018). These beneficiaries included 660,000 women and 86,000 entrepreneurs from the formal sector (APIM, 2015; AFD 2016; AEO -Togo, 2016). In the microfinance, savings and loans system, overall savings amounted to 249 m US\$ and credits to about $207 \mathrm{~m}$ US $\$$, representing $12 \%$ of savings collected by financial institutions as a whole. According to a BCEAO report published 31 March 2018, the outstanding amount of deposits was close to F CFA 200 bn, i.e. nearly double the volume of Benin. Compared with 2017, microfinance deposits rose by $10 \%$ and credits by $10 \%$. The system included about 200 formal microfinance initiatives, with ca. 500 service points nationwide. These initiatives are assisted by the Association Professionelle des Institutions de Microfinance du Togo (APIM-Togo) which was created in 2004 to promote the development of the microfinance industry in Togo. The system is controlled by law of 12 May 2011 on the regulation of Decentralized Financial Systems (DFS). Despite the large number of SFDs the sector remains concentrated in a few cooperative networks. The largest of these networks is the 'Umbrella Organisation of Cooperative Savings and Credit Units of Togo' (FUCEC Togo) and the 'Women and Associations for Gain both Economic and Social' (WAGES), which accounted for about 70\% of the market. In September 2018, the African Financer of Micro-Projects (Financière Africaine de Micro-Projets, FINAM), the first public limited company for microfinance, founded in 2015 , launched the first edition of its 1,000 micro-projects campaign to combat youth unemployment. These can benefit, without prior deposits, but with simple guarantees from members of FINAM, loans up to 600,000 F CFA for the realization of their micro-projects.

\section{Q8 | Currency and Price Stability}

\section{Q8.1 | Anti-inflation / forex policy}

Consumer price inflation remained low due to a sharp decline in fresh food and energy prices. However, because of the relatively strong growth that maintains demand-side inflationary pressures and an increase in global food prices, imported inflation is continuing to remain below the WAEMU convergence criterion of up to $3 \%$. (estimated range of $0.5 \%$ in 2018 to $0.3 \% 2019$ and $0.2 \%$ in 2020 (IMF, 2018). The inflation rate should remain moderate over the coming years due to the currency peg and government subsidies on fuel prices. As a member of the CFA franc zone, the country cannot pursue an independent monetary policy. The West African CFA franc is pegged to the euro at a rate of F CFA 657.88 to $€ 1$. The central bank of WAEMU, the Banque Centrale des Etats de l'Afrique de l'ouest (BCEAO), is meant to control inflation and the viability of the West African CFA franc's peg to the euro. Integration into the franc zone is still mainly justified for political rather than economic reasons. This is because of high exposure of West African countries to a political crisis. However, crucial common denominators of the CFA franc zone are not necessarily in the economic interests of Africa. Its shared colonial heritage, including social and economic infrastructure, oriented to the mise en valeur of African resources for the former colonial power, entails a considerable loss of economic and political sovereignty on the part of African member states. In addition, the 
volatility of the euro, triggered by the global financial crisis and bad governance in some EU member states, shows that the perpetuation of the established monetary structure of the CFA franc zone is increasingly anachronistic. The peg to the EU Economic and Monetary Union (EMU), orientated at the interests of highly industrialized European countries, led to an overvaluation of the real exchange rate of the CFA. This could constitute an obstacle to sustainable indigenous development in francophone Africa. Yet, the major structural deficiencies within and between member states of each zone cannot be solved by monetary coordination alone. Tackling these structural deficiencies requires sustainable political and economic solutions, adapted to the specific needs of each of WAEMU member states, which would enable each member state to take ownership of the measures and instruments. In other words, each government, including the government in Lomé, should get the priorities right, i.e. it ought to first implement sustainable solutions to the problems of crisis resolution and prevention, and the fight against corruption and rent-seeking, to then promote good governance, transparency and accountability.

\section{Q8.2 | Macrostability}

In the past, the government pursued a stability-oriented monetary and fiscal policy. At the end of 2010, Togo had become the 31st country to successfully graduate from the HIPC process of the Heavily Indebted Poor Country (HIPC) Initiative. The IMF and major bilateral donors, e.g., France, Germany and Italy, approved the cancellation of debts. Because of this write-off, the public debt burden fell from $52.7 \%$ of GDP (2009) to $17.2 \%$ (2010), or $32.3 \%$ including debts owed by parastatals. The government implemented the unified revenue authority (Office Togolais des Recettes, OTR) in 2014, merging the customs and tax directorates. However, public debt, including the debts owed by public-sector enterprises, increased again from $44.5 \%$ of GDP at the end of 2011 to an estimated 76.9\% of GDP at end 2017 (EIU, 2018), which was above WAEMU's total public debt limit (70\% of GDP). The IMF was especially concerned that China was overloading Togo with unsustainable debt by its big infrastructure projects. End of 2018, the IMF predicted a decline from 81\% of GDP at end-2016 before the start of the ECF-supported program to $74 \%$ t of GDP by end-December 2018 (or $71 \%$ excluding debt of State-owned enterprises). In 2018, the Chinese premier Mr Xi, therefore, announced a partial debt write-off. The government aimed to cut public debt to $70 \%$ of GDP by end of 2019 by reducing capital investment financed solely by public debt and relying more heavily on partnerships with the private sector. Togo's public debt had already started to decline in 2017 (from 81.3\% at end-2016), and at the end of 2018, Togo was already harmonising its budget management in line with Economic Community of West African States norms. However, its plan to reduce public debt to below 38\% of GDP by 2025 was unrealistic in view of the prevailing political tensions and slow progress in improving the business environment which impedes to attract sufficient FDI. Urged by the IMF, the government agreed to refocus on sustainably financed infrastructure spending and targeted social programs, such as the Programme d'Urgence de Développement Communautaire (PUDC) and Programme d'Appui aux Populations Vulnérables (PAPV), to be integrated into the National Development Plan (PND, 2018-2022). Promising economic growth rates of 5.5 $\%$ on average (2015 to 2018, IMF 2015) are expected to continue up to 2021 due to the benefits of the improved transportation infrastructure and productivity gains in the agricultural sector. The agricultural sector accounted for 47.6\% of GNP in 2015 and employs half the economically active population in Togo. The role of the private sector in driving economic growth was overshadowed by increasing individual and regional inequality as well as 
environmental degradation, which more than offset economic growth (see environment). All in all, the economy and government budget remain volatile and prone to external shocks.

The new budget for 2019 was adopted in parliament as usual at the end of 2018 (17. November). With a total of 1,461 bn F CFA (US\$ 2,227 m), it represented an $11.5 \%$ increase over the 20187 budget. $45 \%$ of the budget was consecrated to expenditures for health, education. Public debt was projected to $67.5 \%$ at the end of 2019 , against $72 \%$ in September 2018. The budget revenue was estimated to increase by F CFA 49,1 bn to 881.1 bn in 2019, against 832 bn in 2018. Budget expenses were fixed at F CFA 895 bn, i.e. 25.6 bn less than in 2018. The deputies of the opposition boycotted the vote en bloc in view of the political crisis. At the occasion of the presentation of the budget in parliament, the opposition complained again about impunity vis à vis tax fraud, mismanagement of parastatals like Togo Telecom, SNPT, the autonomous port of Lomé and the two state-owned banks, etc.

\section{Q9 | Private Property}

\section{Q9.1 | Property rights}

The judicial system does not sufficiently protect private property. The influence exercised by the executive is too strong. Inheritance and property protection laws are deficient, notably for women. Where they exist, they are not adequately enforced. As for most of the laws, contracts are difficult to enforce. The ongoing reform of the judiciary needs to address these issues. Because of the state of quasi-lawlessness in many sectors, there is a substantial black market for illegally imported products, mainly electronics, computer software and cosmetics.

The problem of a complex land-tenure system in which traditional and modem law coexist and compete is exacerbated by land scarcity. The land-tenure regulations are still dominated by traditional African customary laws, re-interpreted by traditional chieftains and local authorities, often to their own advantage, notably in the countryside. Most contracts on agricultural land are still verbal. Disputes over land are extremely common. $80 \%$ of court cases regard land-tenure questions, according to the CVJR. Only about $36 \%$ of arable land is under a tenure system that provides long-term security. Land conflicts and frauds concerning land sold twice are steadily increasing. According to a common saying, conflicts over land are the third important cause of death, behind malaria and HIV. Property rights on land are complex (see traditional authorities) because of the plurality of legal rights and asymmetrical power relationships (between men and women, migrants and 'first comers', elders and young people). In addition, the land tenure regimes change over time because of the historical impact of the introduction of cash crops, the impact of public projects (resettlement, forest reserves, etc.) and contested land privatization through the registration of property titles. Especially poor farmers, migrants and women who have no secure rights are affected negatively. The new land code of 2018 is meant to check this development.

The fight against land grabbings threatens 25,000 ha in Togo, including 53 cases of lease contracts or large-scale land acquisitions (Forum national sur l'accaparement des terres, FOPADESC 2018). Among the rural areas most affected are those with high agricultural potential, such as the prefectures of Amou, Ogou, East-Mono, Haho, Kpélé and Kloto in the plateau region, as well as those on the plain of Mô in the central region. The perpetrators are often affluent officials, politicians or businessmen. They use methods ranging from creating and sustaining inter-community conflicts to outright intimidation. Much of the at-risk land has not been cultivated for several decades and its value is largely speculative. These damaging 
practices threaten the food security of Togo's rural poor since land grabbing deprives rural populations of their main production tool. Stakeholders urged the government to reinforce the legal framework protecting the right to food within its national Food Security Program (PNIASA) and to implement as soon as possible land reforms corresponding to international standards that prevent land grabbing and forced evictions (African Network on the Right to Food, ANoRF-Togo 2013).

\section{Q9.2 | Private enterprise}

A limited sector of small- and medium-sized enterprises cover a greater part of the Togolese' day-to-day consumption needs. But the private sector is comprised primarily of the agricultural sector, which employs $65 \%$ of the country's labour force in both subsistence and small-scale commercial farming. The informal sector still prevails, it provides employment for more than three times as many labourers than the formal sector (see Q16.1). According to the WB-Enterprise Survey of Togo 2016, about 19\% of the 150 firms surveyed started operation without being formally registered. However, $69 \%$ of the $81 \%$ of registered firms declared to face competition with informal firms, an indicator of the prevalence of the informal economy. About $28 \%$ of the enterprises surveyed had a female owner. On a larger scale, there are still many hurdles to developing a stable private sector.

The protection of real property is frequently contentious because of Togo's mix of civil and traditional law. Property registration remains difficult, despite recent reforms and contracts are difficult to enforce. The judicial system lacks resources and is heavily influenced by the presidency, the indices of Property Rights, Government Integrity and Judicial Effectiveness went all down to 32.7, 31.4 and 28.2 points (of 100) according to the Heritage Foundation's 2018 Index of Economic Freedom.

In 2012 the government adopted a new investment code promising equal treatment of domestic and foreign investors. However, investment is permitted only in certain sectors. Every investment must have a minimum value and is screened on a case-by-case basis, which opens doors to bribery. The lack of transparency and predictability and the high informal transaction costs inhibit robust FDI. Foreign exchange accounts need prior government approval. Business-friendly reforms, implemented in 2016, facilitated tax payment and crossborder trade. The overall tax burden equals $28.5 .7 \%$ of domestic income. The top individual income tax rate is $45 \%$, and the highest corporate tax is $27 \%$, although this is rarely paid. About one -quarter of government revenue is provided by tariffs. The average applied tariff rate is $11.4 \%$. However, multiple non-tariff barriers to trade impede foreign trade. The 2018 index of trade- and business freedom declined to 67.2 points (of 100) and 49.7 respectively, whereas Investment freedom improved (65.0) according to the Heritage Foundation.

\section{Q10 | Welfare Regime}

\section{Q10.1 | Social safety nets}

Togo's welfare system is underdeveloped. It is available only to government employees and those employed in the formal sector. Of the economically active population, the majority $(51 \%)$ were small farmers, $39 \%$ independent non-agricultural workers and $9.3 \%$ employed in the formal sector. The latter comprised 88,000 jobs, $67 \%$ in the public sector and $33 \%$ in the private sector. Togo belongs to the 10 African countries in which the public sector represents less than 5\% of total employed (Ibrahim-2018 Index). According to official data presented by 
the government in 2017, the unemployment rate was 1.8\%. and that of youth unemployed 2.8\% (Institut National de la Statistique et des Etudes Economiques et Démographiques, INSEED). However, these figures were questioned as rather politically motivated calculus. According to ILO modelled estimates unemployment was $6.20 \%$ as of 2017 . In addition, the rate of under-employment had increased from $22.8 \%$ (2011) to $24.9 \%$ (2015; INSEED), making a total of at least $28.3 \%$ un- and under-employed mostly young people who represented about $35 \%$ of the population.

The monthly minimum wage (salaire minimum interprofessionnel garanti, SMIG) was increased in 2017 to CFA42,000 ( $€$ 64.03). However, workers complained regularly about precarious working conditions characterized by bad hygienic and security conditions and nonpayment of the minimum wage. In any case, the SMIG is hardly enough to feed an individual for a month, besides it applies only to the formal sector. About $85 \%$ of the population of the working age population is active and at least $28 \%$ under-employed (2018), while youth unemployment is a major problem in urban centres. The government tried to counteract this tendency with limited success by introducing in 2011 a program for unemployed school leavers. PROVONAT (Programme de Promotion du Volontariat au Togo), backed by UNDP was transferred in June 2014 into the National Agency of Volunteers in Togo (Agence Nationale de Volontariat au Togo, ANVT). Since 2011 more than 43,000 candidates have been registered. Overall, 15,921 volunteers participated in the programs, including 34\% women. 4,538 demobilized volunteers were integrated into active live of over 900 reception structures (ANVT, February 2018).

Pension schemes in Togo do not guarantee beneficiaries a decent living. Despite the fact that the median age in Togo is 18.9 years (i.e., almost half of the population is younger than 18), the current system is no longer financially sustainable. The pension entry age for civil servants is 60 , which puts further pressure on the labour market. The state of Togo's health services system is lamentable. In February 2011 parliament adopted a new health insurance law covering the 80,000 public sector employees who have to contribute $3.5 \%$ of their monthly wages. Most individuals suffering hardship or accidents rely either on the help of family (or clan) members or that of traditional mutual assistance schemes. These schemes are self-organized by their members, who provide services either on a rotating basis (e.g., rotating savings clubs (tontines)) or in the event of an emergency (see Q 7.4).

\section{Q10.2 | Equal opportunity}

According to Afrobarometer (2017), Togolese are widely supportive of gender equality when it comes to life opportunities, such as access to education and land, as well as for being elected to public office. But if jobs are scarce, a substantial minority would give priority to men. Most citizens think it's better for a family if a woman is taking care of the household and children, although, in reality, men are dominant even in this domain. Most Togolese endorse promoting universal education for girls and financial autonomy for women, as well as adopting a three-child limit per family.

Most Togolese express tolerant attitudes toward people of different ethnic origin, religion, and nationality. However, very few extend the same tolerance toward people in same-sex relationships. Yet, this applies to the whole of Africa, which is presumed to be a hotbed of homophobia. The latter is allegedly a colonial legacy because anti-gay laws were introduced by Western colonialists. Before colonialism, many traditional cultures were tolerant of different sexualities and gender relations. A new penal code, adopted in November 2015 after years of advocacy by human-rights organizations, strengthened the protections against 
gender-based violence and discrimination based on gender, ethnicity, religion, and other factors. However, the new law reinforced sanctions against people in same-sex relationships. In some regions, it is common for a wife to be considered her husband's property (SIGI, 2016). 33.8\% of women between 15 and 49 are in a polygamous union according to another survey (MICS, 2010). According to rumours, President Gnassinbé himself has nine wives, including, Nana Ama Kufuo, the daughter of former Ghanaian president, but none of them is regarded as first lady. Other gossips claim that he married on 31 March 2012 Yolanda Gnassingbé, a graduate of Princeton University, the First Lady of Togo (fmliberte.com). In 2010, the government, in collaboration with NGOs such as WILDAF Togo and GF2D, supported by UNDP, carried out research and gender-based violence (GBV) in Togo. The study revealed that GBV was widespread across the country, with $94 \%$ of respondents reporting physical violence, 93\% sexual violence and 79\% economic violence. Younger women were more likely than older women to experience physical and psychological violence, with higher rates in the Savanes region. Domestic violence is considered by many to be a private matter that should be solved within the family. Therefore, the police rarely intervene in domestic matters. In general, Togo does not provide equal opportunities to women. The Gender Development Index (GDI, 2018) for Togo is 0.822. Thus Togo is belonging to group 5 of countries with the lowest equality in HDI achievements between women and men.

While access to education has improved for girls, there are still severe disadvantages notably with regard to secondary and higher education. Mean years of schooling of females was only half (3.3 years) of that of males (6.5 years). Just $26.3 \%$ of females (\% ages 25 and older) had at least some secondary education, against $52.5 \%$ of men ((Programme for the Analysis of Education Systems of Confemen, PASEC, 2016; PASEC 2019 not yet published; HDR, 2018). Moreover, the prevalence of violence against women remains troubling: $10 \%$ of women reported having suffered physical abuse during the 12 months, while $4 \%$ said they experienced sexual violence. Only $7 \%$ of victims reported their abuse to authorities (Demographic and Health Survey (EDST), 2013-14). Concerning decision-making in the household, the man is still in the driver's seat. The most important domains in which the woman decide according to the EDST, are women's health care, major purchases for the household and visits to the woman's family or parents. However, even regarding the decision on major purchases for the household, the role of the male spouse is important since he decides mainly in $52 \%$ of cases; women participate in these decisions in $47 \%$ of the cases.

Although women are dominant in the informal sector (e.g., agriculture and petty trade), they have only very limited access to, and control of the factors of production (land, equipment, inputs, credit). In addition, it is highly unlikely that they will get equal access to wage employment in the formal sector in the foreseeable future.

Nevertheless, the exclusion of women from key activities in the economy and politics has slightly improved since 1990. In 2008, the government introduced a national action plan to correct gender inequality (PNEEG - Plan d'Action national pour l'équité et l'égalité de genre au Togo 2009-2013). However, the means to implement this policy are insufficient. Discrimination of women remains widespread. In the most recent UNDP Gender Inequality Index (GII, 0.567, 2017), Togo ranked 140 out of 189 countries. The \%age of girls who completed primary education rose from $55 \%$ (2008) to $79 \%$ (2014), against boys from $77 \%$ to $91 \%$ (World Bank 2016). The mean years of schooling for girls (3.3) were only half of that of boys (6.5) (HDI 2018). Girls are increasingly more disadvantaged vis-à-vis boys as the level of education increases. Only $26.3 \%$ of females had at least some secondary education (\% ages 25 and older) against $52.5 \%$ for the same category of males.

However, gender inequality is most pronounced concerning property rights (land tenure), access to credit and employment. A legal step forward was a law on land rights, adopted by 
the National Assembly in June 2018, which reconciles traditional and modern law in a statute promoting equality for women and men. Another step to protect the rights of women and minorities had been implemented already two years before.

Women are also underrepresented in the political arena (i.e., government, parliament and political parties) and enterprises, with only six female ministers out of 26 in cabinet (2018), 17 women MPs out of 91 (on the base of the 2013 elections; diminished to 15 in the new parliament since 20 December 2018), and two territorial prefects out of 39. Togo amended the national electoral law in 2013, which now requires that candidate lists include equal numbers of men and women. This amendment applied the first time for the 2018 legislative election. In addition, a 2013 law on Political Party and Electoral Campaign Funding provides that 20\% of public funding allocated to political parties be distributed in proportion to the number of women elected in previous legislative elections. The legislative elections (2013) resulted in the election of 17 women deputies out of a total of 91 deputies (17.6\%), compared with 9 $(11 \%)$ in the previous parliament elected in 2007. However, the 2018 elections led again to a decrease of female deputies to 15 MPs. Yet, on 20 January 2019, a woman was elected the first time in history as head of the Togolese parliament. The candidate, Chantal Yawa Tségana, replaced Dama Dramani, also from the ruling party UNIR. Before, Tségana had been national tax inspector. Women have comprised $11.1 \%$ of mayors and $0.38 \%$ of canton chiefs since the 2000s (IMF 2014). The socio-cultural conditions for stronger participation of Togolese women in politics are rather bleak. A survey of Afrobarometer (2018) revealed significant gender differences concerning men and women's interest in political affairs. Just $31 \%$ of women have participated in election campaigns against $52 \%$ of men, and three times more men (27\%) assisted candidates as women (8\%) during the 2010 presidential election.

\section{Q11 | Economic Performance}

\section{Q11.1 | Output strength}

Togo still belongs to the low-income countries with a per capita income of (US\$ 995 or less) (WDI 2018). However, economic growth remained strong at about 5\%, driven by investment in infrastructure and the key cement and clinker sector. Inflation has been below $2 \%$ since 2012 (when it surpassed 3\% per annum). Foreign direct investment has been around $2 \%$ of the GDP since 2012 as well. Public debt, however, has increased from 44.5\% of GDP at the end of 2011 to an estimated 76.9\% of GDP at end of 2017 (EIU, 2018).

Togo's main exports include re-exports, cotton, phosphates, coffee, and cocoa. High rates of underemployment in general (estimated $28 \%$ to $33 \%$ ), notably among recent school levers $(65 \%)$, remain alarming. The current account deficit will gradually narrow from an estimated $7.8 \%$ of GDP in 2018 to $5.4 \%$ of GDP in 2020, driven by rising goods exports, supported by infrastructure investment to improve market access and relatively strong external demand (EUI-4.2018). The overall fiscal deficit (commitment basis) will improve from 9.5\% of GDP at end-2016 to $1.5 \%$ at end-2019 according to the IMF (Dec. 2018). The current-account shortfall will be financed by a combination of foreign direct investment and external loans, mainly on concessional terms.

Apart from domestic problems such as poor infrastructure, an erratic electricity supply, limited foreign investment, the suspension of international aid (1993 - 2007), and an adverse socio-political environment, the increase of imported food and fuel prices in the 1991-2008 period of political instability and subsequent aid crisis also had a severe impact on the economy. Factors like the foreign trade ratio, foreign capital investment and wage incentives have had a strong impact on efficiency. Togo's largest exports in 2016 were gold (US\$ 557 
Millions), cement (US\$ 109 Millions), refined petroleum (US\$ 105 Million), phosphates (US\$ 96.3 Million) and crude petroleum (US\$ 90.1 Million) (Observatory of Economic Complexity, OEC, 2018). Togo once counted among the largest phosphate producers in Africa. Phosphate from the Kpémé deposit in Southern Togo provided $40 \%$ of the country's revenues from exports and made up more than 20\% of Togo's GDP. Since 1997, however, production has fallen from an annual 5.4 million metric tons to 800,000 in 2010, primarily due to corruption and mismanagement. Production increased again to $1.5 \mathrm{~m}$ tons in 2015 ( $27 \%$ of export earnings from minerals, compared with $49 \%$ for clinker and $24 \%$ for gold), and Togo again became the fifths largest phosphate producer worldwide. However, phosphate earnings, representing about $14 \%$ of domestic exports (excluding re-exports) were affected by the volatility of world prices of phosphate, e.g. a price decrease of $24 \%$ in 2014 , combined with a $9.4 \%$ reduction in production due to outdated technical equipment and prolonged strikes in the mining industry in 2015. In 2018, the local firm TFC secured three additional exploration licenses for phosphate in Kara, northern Togo. Industrial growth in 2019-20 will be supported by construction, including construction related to the Adjarala Dam, and by clinker and phosphate production. Services will benefit from the expansion of the port and the airport, and the relatively strong growth in key trading partners such as Niger and Burkina Faso will also support economic activity in Togo (EIU-4.2018).

\section{Q12 | Sustainability}

\section{Q12.1 | Environmental policy}

Environmental degradation and natural resource depletion are mainly due to population pressure, outdated and neglected farming systems, and global climate change. According to the IMF, the current economic growth rates are offset by environmental degradation, primarily through soil and forest resource depletion, coastal erosion, and ambient air and water pollution. Due to the country's failure to accumulate and preserve its physical, financial, and natural wealth, Togo's adjusted net savings, including particulate emission damage (as \% of GNI), became increasingly negative, falling from $-22.1 \%$ in 2010 to $-31.0 \%$ in 2015 when adjusted for environmental degradation (WDI2016). The waterside of the capital losses about 10 meter p.a. because of man-made erosion and smaller villages situated along the coast like Baguida, Gbodjomé, Agborafo successively immerse in the sea (see Q14.2). In the global country ranking of deforestation, Togo ranked at the bottom range (rank 165 of 190 countries) in 2015 (Indexmundi). The forest cover of Togo amounted to $8.5 \%$ or about 486,000 hectares in 2010. Of this, none was classified as primary forest, the most biodiverse form of forest. From 2001 to 2017, Togo lost 43.9 kha of tree cover, equivalent to a $7.9 \%$ decrease since 2000, and 2.68Mt of $\mathrm{CO}_{2}$ of emissions. (Global Forest Watch, 2018). From 1990 to 2015 forest area decreased even more from $12.6 \%$ to $3.5 \%$ (indexmundi). Environmental laws and programs were adopted long ago but are insufficient and poorly enforced. Deforestation rates remain high at an annual rate of $1.4 \%$ (2015). They date back to the early colonial period and the establishment of cotton production for export in a strange alliance between African American emancipation and German imperialism at Tove and surrounding villages. Reforestation attempts have been unable to counteract this development. The high rate of demographic growth (2.84\% p.a.), the slash-and-burn agriculture and the use of wood for fuel have been identified as a major source of deforestation (REDD+, 2018). The government aims to influence a change in habits by subsidizing kerosene and household gas as a substitute for the domestic use of firewood, but to little avail. In October 2015, the government started a $4 \mathrm{~m} \$$ project (2015-2018) to reduce deforestation ("Projet de soutien à la préparation du processus de réduction des émissions à la déforestation et à la dégradation 
des forêts au Togo; REDD+). The project aimed at reinforcing the strategic planning capacity to encounter the environmental and socio-economic effects in view of the still lacking national forest register. A national REDD+ registry and a national forest monitoring system are currently under development. Water pollution presents health hazards and hinders the fishing industry. Air and water pollution is increasing rapidly in urban areas, notably in Lomé (aggregated pollution index: $72.13 \%$; air pollution $62.5 \%$, water pollution $75 \%$; Numbeo, 2018). The government has yet to formulate more specific policies on pollution. However, in 2003, Togo developed a National Biodiversity Strategy and Action. Already in 1988 it had instituted the Environmental Code for the Protection of Fauna, Flora and Natural Areas, in 1990 it launched the National Forestry Action Plan, in 1996 it regulated the Fisheries Resources, National Environmental Policy, and in 2001 it adopted the National Environmental Action Plan.

It should be mentioned, that the environment in most Togolese towns is much cleaner compared to years past, as some waste management efforts have begun to yield improvements. In general, however, eco-friendly consciousness is not well developed, neither by the population nor by producers, including the mining companies, which results in serious environmental pollution (e.g. by phosphate sludge; see the report of FIAN international on the environmental consequences of phosphate extraction in the village of Gnita) and health hazards. In December 2016, Togo and four neighbouring countries (Nigeria, Ghana, Benin, Côte d'Ivoire) agreed to ban imports of dirty fuels from Europe. The imports had been revealed by the Swiss campaign group, Public Eye, in September 2016. They had discovered that retailers were exploiting weak regulatory standards in West Africa, which dated from the colonial era, to export diesel containing levels of toxins that were illegal in Europe. The WHO ranked these health risks among the top global health risks, associated with heart disease, lung cancer and respiratory problems. The new stricter standards should have reduced the sulphur limit in fuels from 3,000 parts per million to 50 (still above the EU limit of 10 p.p.m). However, in Nigeria, a hub of (mostly illegal) fuel exports into the West-African sub-region, stakeholders were still awaiting the enforcement of the ban end of 2018. Thus Nigeria became an easy haven, as well as an illegal entry port for dirty fuels into neighbouring states, including Togo. This the more, because the country's three refineries at Port Harcourt, Warri and Kaduna, continued themselves to sell high-sulphur products. They will have at least until 2021 to meet the new sulphur levels. The refineries in Côte d'Ivoire had similar difficulties to adapt in time and proposed 2025 as a new date for the pullout. West African states, in general, gave themselves an even more accommodating delay in setting 2050 to phase out dirty and inefficient fuel, as Bernard Koffi, spokesman of ECOWAS, disclosed on 20 March 2018 during a conference in Nairobi. West Africa is believed to be Africa's sub-region with the least fuel efficiency and economy levels, as $80 \%$ of the vehicles across the sub-region are old used vehicles, mostly imported from the EU.

\section{Q12.2 | Education policy / R\&D}

After having suffered under the political and economic crises of the past decades, the entire education system has since recovered with remarkable success. Public spending on education. rose from $3.4 \%$ in 2008 to $5.1 \%$ in 2016, it totalled 5.05\% of GDP in 2016 (WDI). Free primary school education was introduced in 2008. As a consequence, the gross enrolment ratio increased considerably. In 2017, the gross enrolment ratio was $123 \%$, with the net enrolment ratio reaching $89.9 \%$ in 2017 , but the net enrolment rate fluctuated substantially in recent years, it tended to increase through 1987 - 2014 period (WDI). The gross enrolment ratio compares favourably with neighbouring African states. Overall the primary school 
completion rate (TAP) varied from 57\% in 2008 to 54\% in 2014 (WDI, latest available data, end of 2018). Though gender inequality persists with mean years of schooling for females (3.3 years) against males (6.5 years) (WDI). The literacy rate of adults ( $\%$ ages 15 and older) was $63.7 \%$ in 2014 . The youth (15 to 24 years) literacy rate stands at $87 \%$ (male) and $79 \%$ (female) in 2015 (UNESCO, 2018). However, the quality of education is worryingly poor. Insufficient and poorly qualified teachers and classes of 50 pupils are common. Increasingly, children aged between 5 and 14 are forced into work due to the poverty of their families. The adult literacy rate remains low (total: $63.75 \%$; male $77.26 \%$; female: $53 \%$ in 2015, UNESCO, 2018). There are strong regional inequalities in education as well, as indicated by the literacy rate (for the same age group) of just $25 \%$ in the Savanes region and $85 \%$ in Lomé, or in general of $43.5 \%$ in rural areas as compared to $79.2 \%$ in urban areas.

Furthermore, universities are overcrowded, lack resources, staff and learning facilities. Because of a lack of state resources, some local communities assumed responsibility for the running schools, notably in the poorest regions in the north. Thus, in the Savanes region, most of the schools were entirely funded by the local community, which supported the building classrooms and paying teachers' wages (UNDP-MDG-report, 2015:67). A representative WBstudy on primary schools in Africa 'What do teachers know and do - Does it matter?', published in January 2017, revealed worrying evidence on the quality of teachers in Togo. None of them met the criteria for a minimum knowledge of language. When it came to understanding and solving a simple math story problem, only about $30 \%$ of Togolese primary school teachers gave a correct answer, and merely 5\% could monitor and comment on the learning progression of their pupils. The minimum knowledge in general pedagogy was $3 \%$. Consequently, the student's knowledge stood well below the African average. Barely $16 \%$ could read a sentence, the overall comprehension score in literacy was 10 out of 100, and just $9 \%$ of pupils could solve a simple math story. Private schools are expensive and not always of better quality. Secondary schooling remains still at a low level. The primary to secondary transition rate was $83.25 \%$ in 2016 , with $86.25 \%$ for males and $79.97 \%$ for females (UNESCO, 2018; secondary completion rate overall $35 \%$ in 2010).

However, the absorption rate of school leavers into the national economy is limited and un- or underemployment among recent school leavers is alarmingly high (estimated 28\% to 33\%).

Research and development remain a neglected area. According to the latest available World Bank figures, R\&D expenditure stood at only $0.3 \%$ of GDP in 2014.

\section{Management Index}

\section{Level of Difficulty}

\section{Q13 | Level of Difficulty}

\section{Q13.1 | Structural constraints}

Togo is a small country with promising natural resources. The population still depends to a large extent on subsistence farming. Major foreign exchange earner is the phosphate sector, clinker, cement and cotton production and (mostly illicit) re-exports, all dependent on volatile terms of trade on the world market. In addition, the country only produces some of the energy that it needs. Togo is dependent on neighbouring Ghana and Nigeria for electricity and gas supply. Access to electrical power remains a luxury for most of the Togolese population, 
whose main source of energy is firewood and charcoal. Togo's electricity production and access have been below the average of regional peers (see Q7.1). Although Togo's performance in terms of providing energy access is improving, the overall access rate in 2015 reached only $29.2 \%$, that is significantly lower than the SSA average of $37 \%$. Moreover, energy access in Togo shows important disparities between urban and rural areas. Whereas in urban areas in urban areas the access rate of $56.4 \%$ is moderate in comparison with other SSA countries, the rate of just $5.5 \%$ for rural areas is even significantly below the average rural electrification rate of $15 \%$ in SSA (WB, 2017). Besides, Togo has among the highest average electricity tariffs in SSA) (USc\$19/kWh), although these tariffs remain still below the cost of the service provider. In March 2017, the population protested against the increase in energy tariffs imposed by the provider in order to reduce the fiscal burden of the sector. The government promised to ensure universal access to power for all Togolese by 2030, with $100 \%$ access rate over the next ten years. In this respect, it counts on private sector investment, notably Public-Private Partnerships (PPP) as well as an intelligent combination of network extension and off-grid technologies.

In July 2017, the government concluded a contract with the English enterprise Bboxx to provide 300,000 domestic solar-home-kits to be distributed in rural areas in the next five years within the framework of the CIZO (enlighten, in Mina, the local language) initiative at an estimated cost of about $117 \mathrm{~m}$ US\$. Thereby, the electrification rate in rural areas was meant to rise from the present 6\% to 35\% in 2022. Launched in August 2017 with a US\$ 975,000 grant from the African Development Bank's (AfDB) African Sustainable Energy Fund (SEFA), Togo's Project CIZO aims to meet $50 \%$ of the electricity needs with solar power by 2030. By the end of 2018, BBOXX had supplied electricity to 26,000 Togolese and opened 20 shops. The European Union (EU) added between $€ 20$ million- $€ 25$ million in capital via AfDB in mid-October, one of the goals being to install off-grid, home solar energy systems in 550,000 Togolese households by 2030 . The government was to provide about $15 \mathrm{~m} \mathrm{US \$ \text {,and }}$ $102.5 \mathrm{~m}$ US\$ will have to be secured from private investors, i.e. to be sold on a pay-as-you-go model using popular mobile payment solutions by the sale of the kits via mobile payments (PAYGO). In the pilot stage, the first 10,000 kits will be delivered for the rural areas within the next year, assisted by initial funding of about $1 \mathrm{~m}$ US $\$$ of the Sustainable Energy Fund for Africa (SEFA), a multi-donor trust fund administered by the African Development Bank.

Migration, accelerated by the political crisis has had a dramatic impact on the country's labour force in the last two decades. The International Organisation for Migration (IOM, Geneva) disclosed on 28. November 2017 that in 2016 more than 330,000 migrants had passed the frontier between Niger and Libya for a European destination, among them at least 300 Togolese. Also, ships under Togolese registration were reported to have carried clandestine migrants to Turkey and European harbours. On 26 April 2018 the Directorate of Maritime Transports (DTM), Lomé, published a list of 36 ships that had been banned from using the Togolese flag of convenience because of engaging in illegal activities from November 2012 to November 2017. Already in February 2017, the national body responsible for state action at sea (ONAEM-Togo, created in 2014), had revealed in its second annual report that of 566 vessels registered in Togo end of 2016 about 200 had to be radiated from the list because they had tarnished the image of the country and acted in illegality. Over the past decades, hundreds of thousand Togolese refugees migrated to Europe in view of political persecution during the political crisis of the 1990s and 2005, notably to France and Germany. However, many of them had to return. In 2107 only 10,615 migrants from Togo still lived in Germany. In 2008, expelled migrants, backed by a German solidarity network for undocumented migrants, organized themselves in the Togolese Association of Expelled Migrants (ATE) with the aim of offering assistance to migrants and defending their rights. On the other hand, there was also 
immigration to Togo mostly for economic reasons. The migrant stock in Togo from 1980 to 2015 totalled 276,844 migrants, most of them from neighbouring Benin, Ghana and Nigeria. Out-migration of Togolese was as well focused on neighbouring states (total 378,439 in 2013), but among the five top destinations figured also France with 23,367 in 2013.

Moreover, trans-national migration of children in search of labour or out of cultural reasons is common not only in Togo but in the whole of West Africa. A project of «Terre des Hommes» registered about 7 million migrant children in the corridor Côte d'Ivoire, Ghana, Togo, Bénin and Nigeria, including about $1 \mathrm{~m}$ children from Togo, as revealed during a conference on child-migration in Lomé on 8 November 2018. Many qualified Togolese can be found in Europe but also in neighbouring West African countries. The lack of good governance, including the ruling elite unwillingness to devolve political power, still constitutes the major single development barrier.

Last, but not least, increasing raw material demand of new global players like China and India provide the much needed stimulus to revive the export industries and to improve Togo's bargaining position in economic cooperation (aid), as big infrastructure projects financed by the Chinese show, e.g. the construction of a new Lomé international airport, the extension of the deep-water harbor, and the reconstruction of major national highways . At the same time, good foreign relations with the new global players allow for a resumption of the see-saw policy already successfully practised during times of the Cold War between competing major donor countries.

\section{Q13.2 | Civil society traditions}

Civil society development flourished with the second wind of change since the early 1990s. Today, there are thousands of NGOs and associations in all spheres of public life that exercise their right to freely express their opinion or form self-help groups (see Interest Groups). This has resulted - mainly in the cities - in the creation of a multitude of different associations, often competing against each other for both the right to represent their clientele and for donor support. There are notable partnerships between various interest groups that have been forged around issues such as human rights, elections, gender and micro-financing. This indeed is a clear sign of agency and a vibrant civil society determined to take its fate in its own hands. Some of these civil society organizations should exercise greater transparency in defining their operational mode and objectives. It remains to be seen whether such associations will gain the same strength in rural areas that they have in urban areas, especially Lomé.

\section{Q13.3 | Conflict intensity}

The high potential for conflict that existed under Gnassingbé Eyadéma's rule through the ethnic polarization and the militarization of society can no longer be considered the one crucial impediment to Togo's development. Yet, both elements still need to be considered. The most important determining factor in conflict remains the power politics of the Gnassingbé clan and its followers. It should be mentioned that Togo has not yet encountered severe tensions between different religious groups. Generally, the relationship between Muslims and Christians is amicable. Cooperation is sought by both groups on many occasions. Transnational conflicts of transhumance between pastoralists and agriculturalists 
are still virulent beneath the surface. Occasional instances of violence occur in about one-third of prefectures, notably in northern and central Togo. Thus, violent conflicts between Fulbe nomads and local peasants of Bago (Central Togo at the Benin border) resulted in 50 dead and over 100 injured persons in August 2011. During the 2016 campaign, conflicts led to the death of five persons. In the meantime, the government put in place a Transhumance Management Plan (TMP) for the regulation of conflicts. During the authorized season from January 30 to May 31 2017, the herdsmen were called to strict compliance with rules and the use of passage corridors. In addition, the herds and their companions had to pay a fee of $\mathrm{F}$ CFA 5,000 FCFA and present an identification badge. For 2017 and 2018, the National Committee of Transhumance (CNT) recorded no serious conflicts or fatalities. Regional inequalities, and sentiments of distrust and mutual antipathy between people in the south and north still need to be addressed. Having enjoyed the spoils of the system throughout much of recent history, northern Kabyé still hold an unduly high number of relevant public offices compared to their counterparts in the south, notably in the security services. There are sharp and increasing differences between the poor and the rich in Togo, but these have not yet led to a situation of violent conflict. Yet, growing discontent among unemployed school leavers contributes to political unrest in urban centres, notably in Lomé.

\section{Management Performance}

\section{Q14 | Steering Capability}

\section{Q14.1 | Prioritization}

It remains unclear whether the political leadership as a whole is committed to political democratization, decentralization and economic liberalization. Nevertheless, major improvements are undeniable. According to the Ibrahim Index of African Governance 2016, Togo counted among the top five best improvers over the past decade for overall governance (rank 33 of 54 in 2015; score 48.5, +9.7, 2006-2015). In the past two years, its rank increased again to rank 30 (score 49.1 (2017), + 5.2 change 2008-2017; Ibrahim Index, 2018). It now ranked between Niger $\left(29^{\text {th }}\right)$ and Gabun (31th); neighbouring Ghana ranked $6^{\text {th }}$ and Benin $15^{\text {th }}$. Yet, on some individual indicators, Togo's performance deteriorated between 2006 and 2015. Actual politics point in the same direction. However, cleavages between hardliners and modernizers within the Gnassingbé clan, the ruling party, and security forces are still simmering. These cleavages have the potential to erupt at any time, especially if the regime's power base in politics and economy is threatened by an electoral defeat. In addition, a broad coalition of radical and moderate political parties together with civic movements demand an end to Gnassingbé's rule.

In 2008 Togo joined the African Peer Review Mechanism (APRM; MAEP, in French) of the NEPAD as 29th member. The APRM is meant to enhance good governance in the sub-region. However, the first efforts to initiate a nationwide evaluation structure in Togo only reluctantly began in 2011. There is a national APRM commission, composed of 37 CSOs, hand-selected by the government, and members of the public administration. A mid-term evaluation of the APRM, including stakeholder analyzes of five West African states (Togo, Ghana, Benin, Mali, Niger, Burkina Faso), completed in February 2016 as well as an ECOWAS APRMworkshop in Abidjan at end of November resulted in mixed findings. The auto-evaluation directed by the national APRM commission is still in progress, including regional seminars for capacity-building of CSOs. Platform members reviewed the Togo State report in the period between May and August 2018, the results are still pending. 
The administration has the support of the international donor community for these efforts. In September 2011, a new defence partnership between France and Togo came into force, which replaced the outdated secret military assistance agreements of the Eyadéma era. Apart from the traditional partners, such as France, Germany and the United States, China and India also supported the country with development aid during the review period. Aid by the new Asian global players is usually not tied to political conditions. In addition to the revitalization of bilateral cooperation, international organizations like the IMF, World Bank, the BOAD and the European Union are also reinforcing their assistance in order to promote good government, democratization and growth in Togo. The first IMF financed three-year Extended Credit Facility (ECF), which had replaced the Poverty Reduction and Growth Facility, expired in 2011. A new ECF was delayed up to January 2017 when a staff-level agreement with the government, subject to approval by IMF Management and the Executive Board for a three year ECF with SDR 176 million (about US\$ 238 million) or $120 \%$ of Togo's quota in the IMF was negotiated. In June 2018, the implementation of the second ECF was evaluated as 'broadly satisfactory'. The full Poverty Reduction Strategy Paper (PRSP) was implemented in 2014. This established the base for Togo's Strategy for Accelerated Growth and Employment Promotion (SCAPE, in French) for 2013-2017. The National Development Plan (NDP; 2018-2022) that replaces SCAPE focuses on stimulating growth by establishing Togo's deepwater port as a logistics hub, creating jobs, agricultural processing, as well as upholding the extractive industries and encouraging manufacturing. Another aim, to establish Lomé as a dynamic financial centre will build on the presence of headquarters of several regional banking and insurance groups, and the development of the digital economy.

The AfDB assisted the government to cope with another serious problem, the man-made coastal erosion. In the middle of 2017, it approved a $41 \mathrm{~m}$ US\$ loan to Togo and Benin for the construction of 28 groynes in order to stabilise the shoreline. According to expert's estimates, the Togolese coastline receded by 10 meters per year on average, and even by up to 20 metres per year east to the deep-water harbour of Lomé. Two national roads along the coast had already been washed away, and the former coastal colonial capital Anecho was threatened with submersion by 2030, which could lead to the displacement of thousands of people. Apart from the negative effects of the construction and extension of the port of Lomé with its impact on sedimentary accumulation by the produced change of sea currents, other human interference had accelerated coastal erosion too. Notably, the illegal harvesting of sand and gravel along the shore for construction purposes.

\section{Q14.3 | Policy learning}

The presidential elections of 2010 and 2015 as well as the legislative elections of 2013 and 2018, passed by largely peacefully, and were considered basically democratic by African peers. This was in stark contrast to the previous 2005 presidential election, with its aftermath of bloody political persecution. Apparently, the Gnassingbé regime had learned from the past. The regime was eager to boost the legitimacy of its irregularly acquired power through peaceful and largely free elections and modernization of the ruling party. Nevertheless, Faure 
Gnassingbé and his party (RPT/UNIR) successfully employed the same 'divide and rule' policy that already his father Eyadéma had successfully used for decades to weaken the opposition movement both by legal and extra-legal means. However, his power is contested by hardliners from his own ranks. The international donor community, in the first place the EU, the IMF, France and USA, supported the government's commitment to modernize and consolidate public finances by providing substantial aid. Nevertheless, they were less concerned with democratization than with regional stability, and the growing terrorist threat of Islamism in the Sahel region (Mali) and Nigeria and Togo's support to combat it. In general, the transition process remains volatile and might easily be reversed when pressure is put on the president, e.g. by hardliners in the military or within the ruling party.

\section{Q15 | Resource Efficiency}

Q15.1 | Efficient use of assets

Togo is still suffering from underutilization of assets and other opportunities which could be used by the government. The new reform processes, assisted by the international donor community, notably the Bretton Woods institutions, have improved an efficiency-oriented governance approach in some areas, e.g. in public administration and finance as well as infrastructure rehabilitation. Examples include a new 64 MW multi-fuel Kékéli-power plant (Kékéli meaning "Aurora" in the Mina language) located in the port area of Lomé connected to the West African Gas Pipeline (WAGP). The concession agreement for the construction, financing and operating was signed by the President and the DG of the pan-African industrial group Eranove that managed similar projects already in Côte d'Ivoire and Senegal since 1996. Other major investments of the state included the new telecommunications network, road rehabilitation, a new international airport and the extension of the deep water harbour as a major hub of West African transit and maritime traffic. However, it will take some time before the structural reforms have an impact, and continuing aid will be crucial to promoting the process. Donor confidence remains the most important resource in providing an initial push towards development in Togo.

A key sector remains education. Whereas most children are now attending school, there are not enough teachers to teach them, despite the high numbers of potential teaching personnel in the country (see Q12.2). Most of the qualified Togolese teachers, waiting for an opportunity to work in their own country again, are still abroad because the former government, suspicious of educators, drove them away. Likewise, decades of political crisis and deficient economic freedom still discouraged private foreign investment. It is difficult to revitalize the confidence of foreign investors, although enhanced competition with new global players like China is good for business.

\section{Q15.2 | Policy coordination}

The commitment of the government to democratization and consolidation of public finances vis à vis the donor community conflicts with the determination of the president and his followers to remain in power whatever the cost. The coordination between the presidency and the prime minister's office, which had not always been smooth, improved with the nomination of Komi Klassou, renowned as a loyalist of the ruling elite, who remained in office since his 
nomination in May 2015 until his demission due to the disappointing results of the legislative elections of 20 December 2018. Because the president apparently still lacks sustainable control of the ANR and the military, he is at pains to restructure the security services' high command. Mid-October 2018 he replaced the head of the ANR colonel Koulemaga Kassawa by colonel Ali Esso Tchakpélé. Tchakpélé is Kabyé from Kara, educated at the officer training school (Efofat) at Pya (village near Kara), the homeland and spiritual centre of the Gnassingbé clan. Thus Faure Gnassingbé continued the policy inherited from his father Eyadéma, to secure key positions of the security services for trusted persons of the same ethnic group and regional origin only. Nevertheless, he still manages the portfolio of defence himself, for fear of coup attempts.

Though steps in the right direction have been made, these have been outweighed by high levels of corruption and criminal practices (drug trafficking, capital flight and moneylaundering) at all levels, including members of the current administration.

\section{Q15.3 | Anti-corruption policy}

Togo ranks among the most corrupt African states (rank 117 of 180 countries (Score: 32, out of 100; Corruption Perceptions Index (CPI), CPI-2017, published in February 2018). Furthermore, the high level of illicit financial flows (IFF) which strongly correlates with money-laundering attracted the concern of the international donor community. Togo had the highest level in terms of FFI in relation to its GDP throughout the 2006-2012 time period, when Togo's IFF averaged 76.3\% of GDP (2008-2013; WB 2016) and reached US\$1,526 billion, i.e. 763 billion CFA francs. FFI reached its peak in 2008 when illicit outflows were equivalent to $160 \%$ of GDP and four times greater than the annual government budget. These IFF came mainly from three sources, i.e. commercial tax evasion, trafficking of bills in international trade and abusive transfer prices, criminal activities such as the drug dealing, illegal transactions on weapons, smuggling, active corruption and the conclusion of corrupt civil servants. In comparison, IFF represented almost 500\% of tax revenues, this ranks Togo second in the world. In relation to the expenditures in the fields of education and health, the IFF are thought to stand respectively for $2,43.9 \%$ and $1,088 \%$ of the rates which place Togo as the first perpetrator worldwide according to the international NGO Global Financial Integrity (2018) and ANCE-Togo, 2018.

A national anti-corruption commission (Commission nationale de lutte contre la corruption et le sabotage économique - CNLCSE) was created in 2001. However, it lacks the political will to combat corruption effectively. Judicial corruption was a problem. There was a widespread perception that lawyers bribed judges to influence the outcome of cases. The court system remained overburdened and understaffed (US-Gov., HR-2017). A World Bank survey of businesses in 2010 revealed that $60 \%$ of the Togolese population believed that the courts were neither impartial nor free from corruption. The whole society is aware of the need to undertake decisive steps to eradicate this problem. However, this seems to be a difficult policy step to take because it would cut the lifeline of large parts of the current Togolese elite and administration. In July 2007, a law against money-laundering was enacted following a serious debate in parliament, although the law has had little effect. The Criminal Code, adopted in 2015, strengthened the anti-corruption measures as well as the new law on antimoney laundering and combating the financing of terrorism (AML/CFT) adopted in 2018. The parliament unanimously adopted this supplementary bill on money laundering and the financing of terrorism in the member states of ECOWAS on 24 April 2018. It is aiming to make Togo's legislation conform with WAEMU norms and FATF (Financial Action Task Force) standards. The Anticorruption Commission (Haute Autorité de Prévention et de Lutte 
contre la Corruption et les Infractions Assimilées, HAPLUCIA), tasked to prevent and investigate corruption, became operational in 2017 (IMF, Dec. 2018). Yet, at least concerning expenditure management, Togo's score on the perceived control of corruption was still below the average of its fellow WAEMU members in 2017, although performance appeared to have improved in recent years according to the IMF (Dec. 2018). The law was also meant to strengthen the capacity of intervention by the National Financial Information Processing Unit (CENFI) created in 2008 and to prevent the use of financial and economic networks for illegal recycling of funds. The law obliges Togolese banks to verify sources abroad they transact with and to surveille the transportation of currencies by air, sea and land more closely for sums exceeding F CFA 15 m (US\$ 25,952). There are serious concerns regarding the link of corruption, money-laundering and drug trafficking as Togo becomes a transit country for all forms of trafficking. In August 2018 the French secret service revealed that Colonel Neyo Takougnadi, imprisoned in 2018, was one of the principal members of a cocaine trafficking network, close to highest circles of the regime in Lomé. He was an officer of the FAT who had been promoted shortly before by the head of state to become chief of the General Staff of the president. Before, he had been director of the national police. Mey Gnassingbé, a younger half-brother of the president, who was married to the daughter of the alleged Togolese drogue baron Mourane Taffa, had been accused already in 2011 of being involved in trafficking. In May 2017, the Franco-Togolese lawyer, Pacôme Adjourouvi, a former classmate of Faure Gnassingbé, was nominated special councillor of the Togolese head of state in the rank of minister. This happened despite corruption-accusations against Adjourouvi, investigated by the French counter-espionage DGSE shortly before. He was accused of having facilitated corruption as a go-between to hand over a 'gift' (7.5 Mio $€)$ of Faure Gnassingbé to the then French prime minister Manuel Valls during his official visit to Lomé in 2016, in order to promote the latter's election campaign for the upcoming French presidentials in 2017. Apparent large-scale corruption affected also the construction of the Gnassingbé Eyadema airport terminal. Its US\$ $75 \mathrm{~m}$ budget mysteriously doubled without any reciprocal improvements. At the Togotelecom US\$30m was allegedly spent on defective equipment. In both cases, obscure deals of Chinese companies with the government arouse suspicion of corruption. In April 2018 the French daily Le Monde published details about another corruption scandal. Apparently, the Gnassingbé clan was probed by the French justice in connection with the Bolloré-affair. The notorious French tycoon Vincent Bolloré, prominent member of Françafrique, a neo-colonial network of the political and business elites in France and francophone Africa, had been suspected of having secured port concessions in Lomé and Conakry (Guinea) by undercharged services $(800,000 €$ for merely $100,000 €)$ provided by the international advertising agency Havas (up to 2017 a $60 \%$ dependency of Bolloré, then sold to Vivendi) to help get African presidents elected, including Faure Gnassingbé in 2010. Apparently, the illicit money had been used in the election campaign of Faure Gnassingbe for the presidentials of 2010. Allegedly, the deal was in exchange for the concession to construct a third container terminal of the port of Lomé by Africa Bolloré Logistics. Moreover, about year later a half-brother of the head of state, Patrick Kodjovi Senam Bolouvi, was promoted to the director of Havas Média Togo in July 2011. Bolloré's son Yannick is chairman and chief executive of Havas, in April 2018 he became also chairman of Vivendi. For additional suspected large-scale corruption in the case of phosphate mining in collusion with the president see Q 7.2.

\section{Q16 | Consensus-Building}

Q16.1 | Consensus on goals 


\section{Democracy}

Following the political upheaval in the aftermath of the contested 2005 presidential elections, the donor community demanded a national dialogue in order to overcome the enduring political cleavages between the government, opposition and civil society, which resulted in the Global Political Accord (GPA) in 2006. However, it was implemented only halfheartedly and finally declared obsolete by the government in 2014. The delayed implementation of major GPA reforms remained a point of contention. A population census, the first since nearly three decades, was duly executed in 2010/2011 and recognized by the population. Moreover, the CVJR delivered its report on HR violations in April 2012. Other important measures meant to guarantee fair and free elections, including local elections, reported time and again since 1987, and again postponed in December 2018, together with the constitutional referendum are still a major point of contention. A domestic process of dialogue between major political parties (Cadre permanent de dialogue et de concertation, CPDC), established in 2009, got stuck several times because of a lack of consensus. On 2 October 2014, the reelected president of the Constitutional Court, Assouma, declared the APG as obsolete and void with the advent of a functioning pluralist parliament. Representatives of the Christian churches appealed repeatedly to the political class to reopen the discussions on contentious institutional and constitutional reforms. Thus, overall consensus on transformation goals remains fragile. There are still some key cleavages running through Togolese society that result from regional and ethnic discriminations, the exclusion of previous opposition movements, and socioeconomic disparities.

From 3 to 9 July 2017 the government organized in addition nationwide 'purification ceremonies'. The latter made allusion to customary religious practices in order to "exorcise the evil", i.e. to appease the victims of gross human rights violations committed in the period 1958 to 2005. Although the four big religious entities (catholic and protestant church, Islam and vodun) acknowledged the importance of such symbolic acts, the population, in general, was little impressed. Therefore, little later the church took sides with the opposition. On 18 September 2017, the Bishops Conference of Togo urged the government to carry out reforms requested by the people in accordance with the 1992 Constitution which had been revised by late General Eyadéma in favour of the Gnassingbé regime in 2002. The Episcopal Conference also denounced the wave of repression as well as "the excessive use of force against fellow citizens, sometimes even in their homes". Last, but not least, it urged the army to adopt a Republican attitude of political neutrality in accordance with the Constitution and advised the regime to refrain from inciting ethnic hatred in the media and social networks. One year later, on 22 November 2018, the Bishops Conference repeated their concerns and warned that an organisation of the upcoming legislative elections (20. Dec.) without prior reforms could result in renewed violence.

In view of growing popular pressure, the UNIR majority in parliament adopted on 19 September 2017 a law proposal for the review of the 1992 Constitution (see Q2.1). However, that proposal excluded decisive points of contention with the opposition on this point such as the introduction of a retroactive presidential term limit in order to end the 50 years-rule of the Gnassingbé regime immediately. Yet, the government majority did not get the required quorum (four-fifths of the deputies of the National Assembly) because the opposition boycotted the vote. Therefore, the head of state had recourse to a constitutional referendum on the law to be held on 16 December 2018 but postponed sine die.

\section{Market Economy}


The majority (e.g., the ruling party and most of the opposition) agree on the country's need to regain economic strength, a view shaped by the severe hardships experienced by many Togolese in everyday life. Political change, demanded by many, is seen as an instrument for achieving urgently needed social and economic development. On the one hand, daily hardships may lead to serious social strife. On the other hand, citizens appear willing to support any government that shows genuine concern for the problems of the majority. In general, the government, ruling party, opposition parties and CSOs are dedicated to the basic principles of a market economy. As a transit-economy, Togo depends on open markets and transnational trade, notably within ECOWAS, and with the markets in neighbouring Ghana and Nigeria. However, because a large part of this trade is informal (including smuggling) the recognition of official rules and regulations on taxation, tax-evasion, money-laundering, capital flight is rather weak. Apart from this, there are divergent views within the ruling elite on the need to protect infant industries and commercial agriculture from unfair foreign trade policies, e.g. within the framework of the controversial EU-West African Economic Partnership Agreements (EPAs). Negotiations on EPAs, which have dragged on since 2002, were increasingly under pressure, as the EU wanted to conclude the deal latest 1 October 2015. Although Brussels adopted a stick and carrot approach to the negotiations, apparently at least five countries, including Nigeria and Togo, still refuse to sign the deal up to the end of the survey period. On 26 November 2018, Togo's national social security fund (CNSS) organized a workshop focused on the elaboration of a national strategy to regularize the informal sector, by providing social security to all. According to Informal Sector Organization, a Togolese government entity, $80 \%$ of the country's economic activity is in the informal sector, both urban and rural (US State Gov. HR report 2017). Togo belonged to the African countries with high reliance on the informal sector (over $40 \%$ of GDP) with ambiguous consequences. The most prominent example is the smuggling of petrol from Nigeria. Spillovers from Nigeria's fuel price policy to Togo, resulted in an unwanted subsidy of Nigerian transfers to the equivalent of at least 3\% of Togo's GDP in 2011, three-quarters of which was captured by petrol smugglers according to IMF studies published in the course of the year 2017. Additional negative externalities were reported on lowering the tax base on petrol in Togo. Other underestimated spillovers concerned regional shocks and the impact of a slowdown in Nigeria which could have a significant impact on Togo too.

\section{Q16.2 | Anti-democratic actors}

The RPT/UNIR's purely anti-democratic elements are no longer as important as they had been before the presidential elections of 2010 and 2015. They are still strong enough, however, to endanger any serious attempt by President Faure Gnassingbé to further democratization and devolve power. President Faure Gnassingbé's imprisoned half-brother, Kpatcha, might play an important role in this respect. Kpatcha and some within the military and RPT/UNIR leadership know about the disadvantages they will have to face in the event of political alternance. Divisions within the ruling elite, i.e. the Gnassingbé clan, the RPT/UNIR and the security services, became apparent once more, during the modernization of the ruling party in 2012 as well as by the refusal of the UNIR majority in parliament to vote in favor of a draft law on changes of the constitution introduced by its own government in June 2014. In addition, democratic principles, as well as a culture of transparency and accountability, are not fully respected among the new elites of Togo, including the opposition. This was shown by the schism of the major opposition party, UFC and ANC. 
The Gnassingbé clan and its followers continue to pursue a policy of creating or stimulating conflicts in order to exercise authoritarian power, as evidenced by the arson attacks on the central markets of Lomé and Kara (January 2013). The attacks were used by the government to harass opposition leaders prior to the 2015 presidential election. In contrast, a report on findings released by the CST on 11 . November 2013 identified several key figures within the regime as the ring-leaders of the market fires.

There are no consistent policies in place to systematically address emerging conflicts in the country. Nevertheless, there have been some positive steps taken. Besides the nationwide capacity building of CSOs promoted by the APRM initiative (s. above), the administration recognized, for example, that the environmental problems arising from nomads and their cattle herds during transhumance, which often leads to problems with settled farmers, whose agricultural production is endangered. Due to the oppressive and corrupt nature of the previous regime, which affected almost every institution in the country, there are few nongovernmental actors that are powerful enough to mediate in actual or future conflicts, with one notable exception the Truth and Reconciliation Commission (CVJR) and the Catholic Church. In general, the NGOs that specialize in conflict prevention and management are not yet strong enough to play a decisive role. Approaches designed to prevent institutional crises can be found also in UNDP backed conflict prevention programs, e.g. concerning the training and deployment of national election observers and mediators. Besides, German political foundations (HSS, KAS) support small projects for crisis prevention in Togo. Examples are the backing of national and regional structures of the African Peer Review Mechanism (APRM) by the HSS and seminars to promote the dialogue between military and parliamentarians as well as the support of HR-organizations like the GF2D, the Conseil National de la Jeunesse (since 2012) and the Groupe de Réflexion et d'Action pour le Dialogue, la Démocratie et le Développement (GRAD). In addition, some few trade unions, NGOs, religious organizations and media outlets created transnational partnerships for conflict prevention, like the West African Network for Education \& Peace (WANEP-Togo) and the Togolese section of WPP-Africa (Women Peacemakers Program - Africa).

\section{Q16.4 | Civil society participation}

The present government seems to be much more open to civil society participation than any previous government. The inefficient use of civil society organizations' capacities is sometimes more due to the weakness of the NGOs' administration and membership structure than to the government's reluctance to engage with them. An enhanced dialogue between CSOs and government is becoming a reality within the APRM initiative. The APRM initiative is composed of $37 \mathrm{CSOs,}$, in addition to members of the public administration. However, the CSOs are hand-selected by the government, which means that more critical parts of civil society tend to be excluded. Both sides must work hard to overcome the deep-rooted distrust in the present situation. 
In May 2009 the Truth and Reconciliation Commission ('Commission Vérité, Justice et Réconciliation', CVJR) was established to investigate human rights violations from 1958 to the bloody persecutions of 2005. It was presided by Mgr. Nicodème Benissan-Barrigah and supported by the UNHCR office in Lomé. The CVJR's 11 members represented different groups of civil society (excluding political parties) and notably involved religious leaders. During its enquiries, it received over 20,000 petitions which indicated a high degree of trust within the population. It submitted its final report in April 2012. The most important recommendations included reparation, public documentation of HR violations, symbolic reconciliation (e. g. public condonation by perpetrators, monuments, memorial days), and last but not least criminal prosecution of perpetrators. The commission demanded that the government publish a white paper stating how it intends to implement the recommendations of the CVJR and suggested two institutions for monitoring and evaluation. Unfortunately, the government is reluctant to implement the recommendations, because high ranking members of the government, military and administration continue to benefit from impunity. Apart from publishing a 'White Paper'(2014) on the implementation of the CVJR's recommendations, considered to be the precondition for the eventual payment of reparation and establishment of a High Commission on Reconciliation (HCR) in 2013 the government applied mainly delaying tactics. A High Commissioner's Office for Reconciliation (Haut Commissariat pour la réconciliation et le renforcement de l'unité nationale, HCRRUN) installed in March 2015 was meant to speed up the implementation of the recommendations, assisted by a CSOplatform (Plateforme citoyenne justice et vérité, PCJV). However, effective functioning was delayed again by transferring contested issues to national discussion groups in July 2016. Nationwide 'purification ceremonies' organised by the government in allusion to customary religious practices in July 2017 in order to "exorcise the evil", i.e. to appease the victims of gross human rights violations committed in the period 1958 to 2005, had little effect.

\section{Q17 | International Cooperation}

\section{Q17.1 | Effective use of support 7}

Togo counts among the largest beneficiaries of international aid. Starting in the late 1970s, international aid dependency increased considerably. Net ODA received (\% of GNI) in Togo was $5.38 \%$ as of 2015 . Its highest value over the past 55 years was $17.64 \%$ in 2009 , while its lowest value was $0.09 \%$ in 1960 .

Resumption of aid and substantial support from donors to the Togolese government started in 2007 after the largely free legislative elections. The numerous activities and cooperation programs such as the ECF, PRGF, SCAPE and HIPC completion point were connected to the progress made in political transformation. However, support from donors was not always used efficiently and transparently. The increasing influence of Asian countries, notably China and India, among international aid donors allows Togo to re-adopt a see-saw policy, which it had practised during the Cold War, of playing competing major donor countries against one another.

Apart from aid, remittances from Togo's diaspora (estimated 2 million people) play a significant role in development. Remittances soared steadily from US\$ $34 \mathrm{~m}$ in 2000, $337 \mathrm{~m}$ in 2010 to $402 \mathrm{~m} 2017$ (WDI, 2018). Remittances have been the largest source of international financial flows to Africa since 2010, accounting on average for about a third of total external financial inflows. They represent the most stable source of flows (AEO, 2018). However, the remittances market served mainly the population in urban centres. It had a comparatively limited payout presence of $44 \%$ in rural areas. According to available data (2009), most inbound payments of remittances in Togo were handled by post offices (38\%), 
banks (23\%) and microfinance institutions (14\%) like Western Union and Money Express. This bottleneck could be overcome by mobile phone money adoption. A scholarly study, published in April 2017, revealed that social groups, including religious and students organizations, were powerful vehicles for the adoption of mobile money in Togo. In contrast, being unemployed decreased the likelihood to adopt mobile money. Although no direct link between remittances and economic growth is discernible, remittances constitute an important supplementary source of financial inflows because they act countercyclical (i.e., remittances increase during downturns) unlike other capital flows like FDI. It is considered to be a more effective means for poverty-alleviation than aid or FDI. However, growing xenophobia in Europe and Africa could threaten future flows of remittances.

\section{Q17.2 | Credibility 7}

International actors appear increasingly trusting of the current government. Traditional partners, such as France, Germany and the United States, and new partners, such as China and India. supported the country with development aid during the review period. In addition to the revitalization of bilateral cooperation, international organizations like the IMF, World Bank, the West African Development Bank and the European Union are also reinforcing their assistance in order to promote good governance, democratization and inclusive economic growth in Togo.

To consolidate the government's newly acquired credibility among the international community and among the Togolese population, the government's most important task is to tackle corruption at all levels of the state, facilitate political competition and devolve power. There are currently two deeply contrasting interpretations of the government's actual intentions, both among the Togolese population and the international donor community. One perspective holds that the government is genuinely pursuing political transformation and that a democratic era has just begun, while a second perspective holds that the government's attitude is camouflaging its attempt to stay in power at all costs.

Given security concerns in the region, international donors increasingly trust - or want to trust - the Togolese government. The military cooperation agreement between Togo and France from 2010 is a case in point. However, in May 2017, France, the biggest supplier of arms for Togo, had been reluctant to proceed in the delivery of five French military helicopters type Gazelle to Lomé in view of the ongoing political crisis. At the same time, the FrancoTogolese lawyer, Pacôme Adjourouvi, a former classmate of Faure Gnassingbé, was nominated special councillor of the Togolese head of state in the rank of minister. This happened despite corruption-accusations against Adjourouvi, investigated by the French counter-espionage DGSE shortly before. He was accused of having facilitated corruption as a go-between to hand over a 'gift' $(7.5$ Mio $€$ ) of Faure Gnassingbé to the then French prime minister Manuel Valls during his official visit to Lomé in 2016, in order to promote the latter's election campaign for the upcoming French presidentials in 2017.

Togo continued to participate in peacekeeping missions of the AU and ECOWAS with about 1,400 soldiers and policemen, especially in Mali. On 1 April 2017, the Togolese Gilbert F. Houngbo became the sixth President of the International Fund for Agricultural Development (IFAD). He previously served as Deputy Director-General of the International Labour Organization (ILO), and from 2008 to 2012, as Prime Minister of Togo. 


\section{Q17.3| Regional cooperation $\quad 8$}

Togo is a member of all relevant regional, African and international organizations, notably of ECOWAS and WAEMU in the West African sub-region. President Faure Gnassingbe and members of his government are trying to return to a situation where Togo plays a constructive role as regional mediator and host to international meetings as in the 'glorious past' of the father of the incumbent, General Eyadéma The latter was recognized as mediator in international African conflicts by his African peers, although being the longest serving African dictator. Togo remained a reliable and significant contributor to peacekeeping missions in the sub-region. In May 2012 Nigeria, Togo, Ivory Coast and Senegal contributed to the ECOWAS force's first troop deployment in the failed state of Guinea Bissau. Later on, Lomé contributed to the African-led International Support Mission to Mali (AFISMA) organized by ECOWAS against the growing threat of Islamist terror organizations in northern Mali as well as to the UN-led MINUSMA (United Nations Multidimensional Integrated Stabilization Mission in Mali) corresponding to a Security Council resolution 2164 of 25 June 2014. From 15 to 18 May 2018 Togo participated in a joint anti-terror operation of 2,902 security forces of Burkina Faso, Benin, Ghana and Togo against banditry and trans-border criminality in the border region. Altogether 200 persons were arrested, most of them (95) in Togo.

In November 2017 Faure Gnassingbé announced that the AU and ECOWAS would be prepared to mediate to put an end to Togo's crisis. The opposition agreed, however, political actors disagreed on the dialogue's nature, format, objectives and prerequisites. The stalemate continued until shortly before the legislative elections in December 2018. End of December the ECOWAS on its 54. Session of the head of states in Abuja officially terminated its facilitating mandate.

At the $51^{\text {st }}$ ordinary ECOWAS summit, held early June 2017 in Liberia for the first time since 30 years, the Togolese head of state was elected the new chairperson (4 June) for one year. He replaced Liberia's President Ellen Johnson Sirleaf, who had been the first female ECOWAS leader. The decision was hailed among others by Israel's Prime Minister Benjamin Netanyahu, who was one of the speakers to the summit. This was the first visit of an Israeli prime minister to Sub-Saharan Africa in 30 years. The renewed Israeli interest was last, but not least, due to its desire to secure Africa's diplomatic backing on Israel-related issues in international forums such as the UN. In addition, Israel offered cooperation in questions of counterterrorism and economic development. Among others, it signed a four-year US $\$ 1 \mathrm{bn}$ treaty to develop green energy projects across the (ECOWAS). During the ECOWAS summit, Netanyahu urged West African leaders to vote for an African-Israel summit in October to be held in Lomé in order to intensify cooperation. This summit, the first ever, was meant to consolidate the rapprochement between Israel and a number of African states which had been made a diplomatic priority of the Israeli government. Togo had longstanding friendly ties with Tel Aviv, notably concerning close cooperation with Israel's security services (Mossad) that had provided sophisticated advice, hard- and software already since the reign of late General Eyadéma. The latest remarkable provision had been in 2013 when Israel delivered listening and security material to the tune of more than $144 \mathrm{~m} €$, i.e. about the double of the budget of Togolese's army. Togo counted also to the few developing countries that voted along with the USA against the UN resolution condemning President Trump's decision to recognize Jerusalem as the capital of Israel at the end of the year. However, there was a controversy about the expediency of the Israel-Africa summit. It was questioned not only by the Togolese 
opposition in view of the actual political domestic crisis but also because of reservations of Maghreb Africa, South Africa and Arab states concerning Israel's position on the Palestine question. Some Islamic African countries like Gabun, Niger, Mali, Mauritania looked on the official intrusion of Israel into Africa as a provocation and called for a boycott of the summit. Still, in September, Senegal condemned Israel's creeping colonisation of Palestine territory. Member states of the OCI (Organisation de la Conference Islamique), to which Togo belonged already since 1997, furiously demanded reprisals against Togo. The king of Marco, Mohammed VI had already boycotted the ECOWAS summit in Monrovia because of the presence of the Israeli Prime Minister. Faure Gnassingbé, who had visited Jerusalem in September succeeded nevertheless to convince most of his pairs to held the Africa-Israel summit. The conference took place in Lomé from 24. to 26. October, with about 30 of 55 African states represented, among them Rwanda, Kenya, Uganda, Congo Brazzaville, Cameroon, Côte d'Ivoire and Ghana.

In view of the increasing bloody violence in Togo and its possible repercussions on the whole sub-region, West African leaders broke finally their silence on Togo's domestic politics. On 25 October 2017, the ECOWAS head of states, who were following a meeting in Niger, stressed the need for negotiations and condemned violent actions by the Togolese police against opponents of the regime while calling for sanctions for any perpetrator of violent actions. On the $52^{\text {nd }}$ ECOWAS-summit in Abuja (Nigeria) in mid of December 2017, which was dedicated among others to discuss the security crisis in Guinea-Bissau and the political crisis in Togo, the members elected its new President of the Commissions (as distinct from the Chairman). The present Ivorian minister of mines Jean-Claude Brou replaced Marcel De Souza from Benin who was married to one of the sisters of Faure Gnassingbé, Naka Gnassingbé.

Yet, most attempts to mediate in the Togolese crisis failed because the mediators proposed by ECOWAS apparently were not neutral. The first effort by the UN special representative for West Africa, the Ghanaian Mohamed Ibn Chambas, was refused by the opposition because the latter was apparently close to the Gnassingbé family. During his tenure as general secretary of ECOWAS (2002-2009), Chambas was suspected to have been one of the architects of the bloody and undemocratic enthronization of Faure Gnassingbé as Togolese head of state and heir of his father Eyadéma in 2005. The Togolese opposition, therefore, filed an action against Ibn Chambas at the UN Ethics Office on 29 September 2017. A similar mistrust applied against another mediator, the minister of foreign affairs of Niger, Mme. Aïchatou Mindaoudou, who was meant to lead a mediation mission of the OIF in Lomé from 10 to 13 October which however was postponed sine die. A third mediation effort of the president of the AU, the Guinean President Alpha Condé mid of October in Lomé was postponed as well in view of the bloody repression of anti-government demonstrations on 18 . to 19. October 2017. End of October, Patrice Talon, the President of Benin, and the Ivorian President Alassane Ouattara tried to mediate in the Togolese crisis in vain too. The Nigeria leader Muhammadu Buhari warned in November that the political instability in Togo could have regional consequences. Some month before, on 14 March 2017, Buhari had signed a treaty with neighbouring governments to construct a highway linking the Nigerian commercial capital Lagos with the Ivorian capital Abidjan via Benin and Togo in order to facilitate international trade and exchange.

From 17 to 21 March 2018 African leaders held an extraordinary summit in Kigali (Rwanda) to create an African Continental Free Trade Area (Af-CFTA / ZLECA, in French). In total 44 out of $55 \mathrm{AU}$ members signed the agreement, 47 signed the complementary Kigali Declaration and 30 the Protocol on Free Movement. Togo signed all three agreements. On 1 
July 2018, five additional countries, including South Africa joint in, bringing the total number of signatories to 49. The Agreement envisages creating a free market for the 55 African states with a population of more than one billion inhabitants. It requires members to remove tariffs from $90 \%$ of goods allowing free access to commodities, goods and services across the continent. According to the United Nations, Economic Commission for Africa (ECA) estimates the Agreement will boost Intra-African trade by $52 \%$ by 2022 . However, the impact of the agreement will remain uncertain as long as heavy-weight Nigeria refuses to sign because it wants to protect its infant industry.

Moreover, Togo is trying to access the British Commonwealth. It embarked on the process since 2014 and missions have multiplied since 2017 in the Togolese capital. If successful, Togo would be the third francophone African country after Rwanda, the second African country to join the Commonwealth in 2009 after Mozambique. Portuguese-speaking Mozambique became the first member never to have had a past link to Britain. In February and June 2017, Commonwealth experts met members of Togolese institutions including the constitutional court, electoral commission and human rights body to evaluate Togo's bid. They also met members of political parties, civil society, women and youth groups to assess levels of democracy and development. British Togoland chose in 1957 to become part of newborn independent Ghana and thus joined the Commonwealth already six decades ago. Decisions by the Commonwealth are made by the 52 heads of governments, who laid out clear criteria for any country wishing to join. This includes the acceptance of Commonwealth fundamental values and principles, such as a commitment to democracy, the rule of law and independence of the judiciary, the protection of human rights, and equality of opportunity. Togo's political opposition and human rights campaigners have expressed concerns about the bid for membership. A decision on membership was expected to be taken at the Commonwealth Heads of Government (CHOGM) meeting in Britain in April 2018. However, the decision had been postponed.

On 15 December 2015, Saudi Arabia announced the formation of an Islamic military alliance to fight terrorism. The initiative was explicitly not restricted to countering the so-called Islamic State, but was intended to combat all forms of terrorism worldwide, and included 34 member countries. Beside 10 Islamic countries, including nations with large and established armies such as Pakistan, Turkey and Egypt, 20 African countries joined the alliance, including Togo, Nigeria and Ivory Coast, each also a member of the Organisation of Islamic Cooperation (OIC), and forming about $60 \%$ of all OIC member states. As of November 2017, there were 41 member countries, all of them with Sunni-dominated governments. The alliance does not include any countries with Shia-dominated governments, such as Iran, Iraq and Syria. Last, but not least, Togo signed the Charter on Maritime Security within the framework of the Africa Integrated Maritime Strategy (2050 AIMS Strategy) in November 2016.

\section{Strategic Outlook}

Like most sub-Saharan African countries, Togo faces several substantial challenges, including a lack of good governance, volatile economic growth, exposure to external economic shocks, rising food costs, erratic energy prices and major environmental risks. But there are key issues the country should address if it is to reach a level of development on par with that achieved by more successful West African countries (e.g., Benin and Ghana). 
In view of the turmoil of the large-scale anti-government protests of September 2017 and December 2018 Togo's government should not reduce its democratization efforts, in order to win the trust and confidence of its own population and the international community. Democratic and institutional reforms implemented over the recent years are not sufficient to gain the confidence of the vast majority of the people, at least concerning the major issue of content, the retroactive limitation of the mandate of the president and political alternation. Many Togolese citizens and observers remain sceptical of whether these reforms reflect a genuine attempt by the Gnassingbé regime to promote democracy in Togo.

The government should transparently pursue national reconciliation, democratization and sustainable economic development on the base of internationally accepted principles of good governance. Especially, it should organize free and fair local elections in 2019 which had been postponed time and again.

In order to overcome some of Togo's endemic development problems (i.e., over-centralized decision-making processes, the undemocratic dominance of the ruling party, the distance between the ruling elite and political realities, and regionalism), support for decentralization should be enhanced. The government must stop obstructing the further devolution of power and resources, which is required by the constitution and necessary to enhance local autonomy. In addition, the devolution of power and resources should be accompanied by support for civil society organizations at local and national levels.

The transition process will not succeed if the government remains under pressure from hardliners within the ruling party and security services. Therefore, it is imperative to guarantee the strict political neutrality of the security forces, notably the military, intelligence service and gendarmerie.

Concerning economics, structural reform of the banking, and phosphate and cotton sectors is crucial. Donors should make additional efforts to support this process. The fight against corruption, money-laundering, capital flight and embezzlement of public funds in Togo's public administration constitutes another significant step on the road to democratization. Last, it is important to support the process of regional integration in West Africa. Any attempts to undermine political initiatives of regional integration (e.g., by special arrangements within the current negotiations on EU-West African EPAs) should be prevented. Greater economic and political integration would benefit all stakeholders. In addition, peacekeeping initiatives and observation measures in the West African region should be promoted. 


\section{References and further reading (hyperlinked)}

28 Too Many (2018) : Togo: the law and FGM. London: September 2018, https://www.28toomany.org/

Ade et al (2014) : Evaluation de la coopération de l'Union européenne avec la République Togolaise 2007-2013 [commanditée par l'Unité d'évaluation de la Direction Générale Dévelopement et Coopération - EuropeAid, CE]. Rapport final provisoire révisé, o.O.

AfDB (2018): Togo - African Economic Outlook. Abidjan: African Development Bank

AfDB (2016): Togo 2016 - 2020. Country Strategy Paper. Abidjan: African Development Bank

African Economic Outlook (AEO) (2016): Togo (country report 2016): Paris: OECD Development Centre

Afrobarometer (2017): Résumé des Résultats 7ème Tour de l'Afrobaromètre Enquête au Togo, 2017. Accra

Agbodji, Akoété Ega \& Yélé Maweki Batana \& Dénis Ouedraogo (2015): Gender inequality in multidimensional welfare deprivation in West Africa: The case of Burkina Faso and Togo, International Journal of Social Economics, 42 (2015) 11: 980 - 1004

Ahianyo-Akakpo, A. (2017): L'impact de la migration sur la société villagoise: approche sociologique (example Togo - Ghana). In : Modern Migrations in Western Africa, Edited By Samir Amin, Edition 1st Edition, First Published 19 January 2017 London: Imprint Routledge, Pages 442 pages

Ahlin, Ekoutiam A. et al (2015): The 2015 presidential election in Togo. Electoral Studies 39, 2015: $153-$ 177

Amnesty International (AI) (2018) : Togo. Berlin,März 2018

Batchana, Essohanam (2014): TOGO : Quels repères pour un pays en quête de son identité nationale (1958-2010). Sciences Humaines, Vol. 1, No 3 (2014), pp. 37 - 61

Blédé, Barthélémy \& André Diouf (2016): Togo's maritime challenges: Why security remains a major issue. Pretoria: Institute for Security Studies, ISS, West Africa Report, Issue 18, August 2016

Breuer, A et al. (2017): Decentralization in Togo. The Contribution of ICT-Based Participatory Development Approaches to Strengthening Local Governance. Bonn: DIE, Discussion Paper 6/2017

CNDH (2018) : Rapport d'activites - Exercice 2017. Lomé : Commisssion Nationale des Droits de L'Homme

CVJR (2012): Rapport final. Lomé: Commission Vérité, Justice et Réconciliation (CVJR)

CIVICUS (2006): A diagnostic study of Togolese Civil Society. Lomé : CIVICUS World Alliance for Citizen Participation

Damome, Étienne (2018): Religions and media in Ghana and Togo. Revue Francaise des Sciences de l'Information et de la Communication. vol. 13, 2018

Dourma, Narcisse Marwanga (2018): L'indépendance de la Justice pénale au Togo aux prises avec les pesanteurs socio-politiques. ResearchGate 
Economist Intelligence Unit: Democracy Index 2017 - Free speech under attack. London: EIU

Environmental Performance index (Yale University) - 2016 Report Freedom House: Country Report Togo 2016. Washington D.C., Freedom HouseFreedom House: Freedom of the Press 2016 report. Washington D.C. Freedom House

FES (2018): Togo 2017. Barometre des medias Africains. Première analyse locale du paysageédiatique en Afrique. Windhoek: Friedrich-Ebert-Stiftung (FES)

Freedom House (2018): Freedom in the world - Togo - 2018. Washington D.C.

Goeh-Akue, Pr. N'buéké Adovi (2013): Etude sur le paysage syndicale au Togo. Lomé : FES

Golup, S.S. (2012): Entrepôt trade and smuggling in West Africa: Benin, Togo and Nigeria. The World Economy, 35 (2012) 9:1139-1161 Helliwell, J. F. / Richard Layard and Jeffrey Sachs (eds.)(2015): World Happiness Report 2015. New York: Sustainable Development Solutions Network

Heritage Foundation: 2018 Index of Economic Freedom (2018): Togo. Washington DC

Ibrahim Index of African Governance (IIAG) 2018. London: Mo Ibrahim Foundation

IMF (2014): Togo. Poverty reduction strategy paper - Joint staff advisory note, Washington D.C. : International Monetary Fonds

IMF (2016): Togo and the IMF (2016): Washington D.C., International Monetary Fonds

IMF (2018): Togo - Country report. IMF Country Report No. 18/362, Washington D.C. December 2018

Index of Economic Freedom - The Heritage Foundation - 2016. Country Rankings. Togo

Kohnert, D. (2011): Togo: Thorny transitions and misguided aid at the roots of economic misery. In: Saine, A. / N 'Diaye, B. / Houngnikpoet, M. (eds.): Elections and democratization in West Africa 1990 - 2009. Trenton: Africa World Press, 2011: 179-210

Kohnert, D. (2014): African Agency and EU- African Economic Partnership Agreements. Review Article. Africa Spectrum, 49 (2014) 3: 149-155

Kohnert, Dirk (2016): Donor's double talk undermines African agency in countries under an aid regime Comparative study of civic agency in Burkina Faso and Togo. Conference Paper, APAD-Conference, Cotonou; forthcoming in: cahier APAD / Anthropologie \& développement

Kohnert, Dirk (2017): Togo: Political and Socio-Economic Development (2015- 2017). MPRARePEc-paper, Sept. 2017

Lelart, Michel (1990) : La tontine pratique informelle d'épargne et de crédit dans les pays en voie de développement. Lomé

LTDH (2018): Togo : La répression et la torture contre le changement démocratique. 19 Août 2017-20 juillet 2018. Lomé: LIGUE TOGOLAISE DES DROITS DE L'HOMME

Marguerat, Yves (1988): L'état et l'organisation territoriale du Togo. Afrique Contemporaine, 145 (1988):47-54

Morency-Laflamme, Julien (2017): A question of trust: military defection during regime crises in Benin and Togo, Democratization, DOI: 10.1080/13510347.2017.1375474 
Napala, K. (2014) : La resistance « Paganiste» des kabiye a l'implantation chretienne entre 1926 et 1960 : The kabiyè pagan resistance to christianity from 1926 to 1960. Journal de la Recherche Scientifique de l'Universite de Lome, Vol 15, No 3 (2014) pp. 169-182

National Assembly (2018): Composition of the new parliament. Based on the 20 December legislative elections. Lomé, 26.12.19

OECD (2013): Gender and state-building in fragile and conflict-affected states. Paris: OECD

PNUD (2007): Profil de la pauvreté et de la vulnérabilité au Togo. Version 2, Lomé : UNDP/PNUD

PNUD (2008): Etude - Diagnostic sur la société civil au Togo. Rapport final. Lomé : UNDP/PNUD

PNUD (2012): Point sur le processus de décentralisation au Togo et l'appui au PNUD. Lomé : UNDP/PNUD

PNUD/UNDP (2018): Programme national d'appui à la décentralisation et à la mise en place des collectivités locales prenant en compte le développement institutionnel des collectivités locales et la formation des acteurs de la décentralisation. Lomé : UNDP, Notice de selection pour le consultant. Date : 7 Novembre 2018

Public Eye (2016): 'Dirty Diesel' - Swiss Commodity Traders Flood Africa with Toxic Fuel. Berne, 15. September 2016

Raunet, Nathalie (2016): Chiefs, migrants and the state: Mobility in the Ghana-Togo borderlands. IMI / Univ. of Oxford, COMPAS Working Paper 131, May 2016

REDD+Togo (2018) : Etude sur les causes et consequences de la deforestation et la degradation des forets au Togo et identification des axes d'intervention appropies. Lomé : Republique Togolaise, 30.03.2018

REDD-Togo (2016) : Ateliers d'information et d'echanges avec la chefferie traditionelle sur le processus REDD+ au Togo. Lomé : MINISTERE DE L'ENVIRONNEMENT ET DES RESSOURCES FORESTIERES, 2017

RT (2015) : Enquête Démographique et de Santé au Togo 2013-2014. Ministère de la Planification, du Développement et de l'Aménagement du Territoire (MPDAT), Ministère de la Santé (MS) et ICF International, 2015. Rockville, Maryland, USA : MPDAT, MS et ICF International

Tcham, Badjow (2010): Regionalisme et histoire: La perceptions de la question Nord/Sud dans l'histoire des Togolais. In: GOEH-AKUE, N. A. \& N. L. GAYIBOR (eds.) (2010): HISTOIRES NATIONALES ET/OU IDENTITES ETHNIQUES. UN DILEMME POUR LES HISTORIENS AFRICAINS ? Presses de l' UL /l'Harmattan, Paris-Lomé, 2010: 193-210

Transparency International - Corruption Perceptions Index 2017, Berlin : February 2018

UE-MOE (2007): Mission d'observation électorale de l'Union Européenne au Togo - Élections législatives du 14 Octobre 2007. Rapport final. Brussels : European Union, Election Observation Mission (EOM), Togo

UE-MOE (2010): Mission d'observation électorale de l'Union Européenne au Togo - Élection présidentielle Mars 2010. Rapport final. Brussels : European Union, Election Observation Mission (EOM), Togo

UNHRC (2014): Report of the Special Rapporteur on the situation of human rights defenders. Mission to Togo, A/HRC/25/55/Add.2, 2014. New York: United Nations - Human Rights Council (OHCHR) 
UNHRC (2016): Togo - National report submitted in accordance with paragraph 5 of the annex to Human Rights Council resolution 16/21*. Working Group on the Universal Periodic Review. Twenty-sixth session. 31 October-11 November 2016. United Nations - Human Rights Council (OHCHR)

UNHRC (2017): Outcome of the universal periodic review: Togo. New York: UN Decision adopted by the Human Rights Council on 16 March 2017. 34/101.A/HRC/DEC/34/101

UNICEF (2008): Étude sur les mutilations génitales féminines au Togo. Rep. Togolaise /UNICEF. Lomè

United Nations: World Happiness Report - 2016 UNODC (2013): Transnational organized crime in West Africa: A threat assessment. Geneva: United Nations Office on Drugs and Crime, Febr. 2013

US Department of State (2015): 2015 Investment climate statement. Washington D.C.

US-Department of State (2015): 2014 trafficking in persons report - Togo. Washington: June 2014

US-Department of State (2018): Togo 2017 - International religious freedom report. Washington.

World Bank (2016): Systematic Country Diagnostic. Washington D.C., September 19, 2016World Bank (2017): Doing business 2017. Togo. Doing Business 2017. 14 ${ }^{\text {th }}$ ed. Equal opportunity for all Washington D.C.

World Bank (2017):. Economic Profile - 2017: Togo. Washington D.C.: World Bank

World Bank (2017): Enterprise Survey - Togo country profile, 2016. Washington D.C.: World Bank

World Bank (2017): Togo energy sector support and investment project. Project appraisal report. Report No: PAD2304. Lomé

World Bank (2018): Doing Business. Economy Profile of Togo. Doing Business 2018 Indicators

World Database of Happiness (2017). Ruut Veenhoven, Erasmus University Rotterdam, Happiness Economics Research Organization 